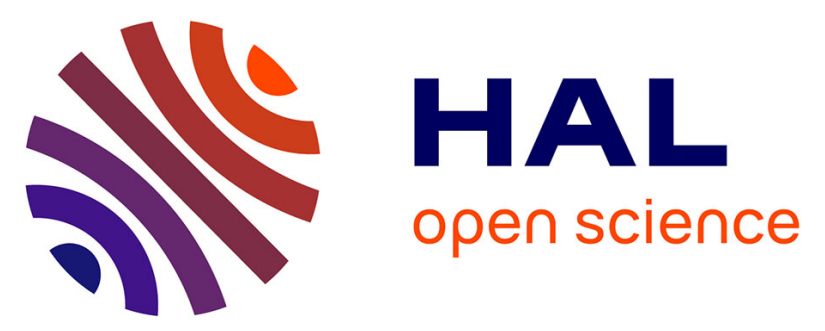

\title{
Somatostatin analogue pasireotide (SOM230) inhibits catecholamine secretion in human pheochromocytoma cells
}

Laura Streit, Sophie Moog, Sylvain Hugel, Marion Rame, Emeline Tanguy, Virginie Andry, Herbert Schmid, Laurent Brunaud, Florence Bihain, Claire Nominé-Criqui, et al.

\section{To cite this version:}

Laura Streit, Sophie Moog, Sylvain Hugel, Marion Rame, Emeline Tanguy, et al.. Somatostatin analogue pasireotide (SOM230) inhibits catecholamine secretion in human pheochromocytoma cells. Cancer Letters, 2021, 524, pp.232-244. 10.1016/j.canlet.2021.10.009 . hal-03389020

\author{
HAL Id: hal-03389020 \\ https://hal.science/hal-03389020
}

Submitted on 20 Oct 2021

HAL is a multi-disciplinary open access archive for the deposit and dissemination of scientific research documents, whether they are published or not. The documents may come from teaching and research institutions in France or abroad, or from public or private research centers.
L'archive ouverte pluridisciplinaire HAL, est destinée au dépôt et à la diffusion de documents scientifiques de niveau recherche, publiés ou non, émanant des établissements d'enseignement et de recherche français ou étrangers, des laboratoires publics ou privés. 


\section{Journal Pre-proof}

Somatostatin analogue pasireotide (SOM230) inhibits catecholamine secretion in human pheochromocytoma cells

Laura Streit, Sophie Moog, Sylvain Hugel, Marion Rame, Emeline Tanguy, Virginie Andry, Herbert A. Schmid, Laurent Brunaud, Florence Bihain, Claire Nominé-Criqui, Yannick Goumon, Stéphanie Lacomme, Sandra Lomazzi, Michel Vix, Didier Mutter, Nicolas Vitale, Stéphane Ory, Stéphane Gasman

PII: S0304-3835(21)00519-X

DOI: https://doi.org/10.1016/j.canlet.2021.10.009

Reference: CAN 115443

To appear in: Cancer Letters

Received Date: 25 May 2021

Revised Date: 22 September 2021

Accepted Date: 6 October 2021

Please cite this article as: L. Streit, S. Moog, S. Hugel, M. Rame, E. Tanguy, V. Andry, H.A. Schmid, L. Brunaud, F. Bihain, C. Nominé-Criqui, Y. Goumon, Sté. Lacomme, S. Lomazzi, M. Vix, D. Mutter, N. Vitale, Sté. Ory, Sté. Gasman, Somatostatin analogue pasireotide (SOM230) inhibits catecholamine secretion in human pheochromocytoma cells, Cancer Letters (2021), doi: https://doi.org/10.1016/ j.canlet.2021.10.009.

This is a PDF file of an article that has undergone enhancements after acceptance, such as the addition of a cover page and metadata, and formatting for readability, but it is not yet the definitive version of record. This version will undergo additional copyediting, typesetting and review before it is published in its final form, but we are providing this version to give early visibility of the article. Please note that, during the production process, errors may be discovered which could affect the content, and all legal disclaimers that apply to the journal pertain.

C 2021 Published by Elsevier B.V. 


\section{Author contribution:}

Laura Streit: Conceptualization, Investigation, Formal analysis, Validation, writing (review \& editing)

Sophie Moog: Investigation, Formal analysis

Sylvain Hugel: Investigation, Formal analysis, Methodology

Marion Rame: Investigation, Formal analysis

Emeline Tanguy: Investigation, Formal analysis, writing (review \& editing)

Virginie Andry: Investigation, Formal analysis

Herbert A. Schmid: Resources, Methodology

Laurent Brunaud : Supervision, Resources, Funding acquisition, Methodology

Florence Bihain : Resources, Methodology

Claire Nominé-Criqui : Resources, Methodology

Yannick Goumon: Investigation, Formal analysis, Methodology

Stéphanie Lacomme : Investigation, Formal analysis, Data curation, Validation

Sandra Lomazzi : Investigation, Formal analysis, Data curation, Validation

Michel Vix : Resources, Methodology

Didier Mutter : Resources, Methodology

Nicolas Vitale : Conceptualization, Investigation, Formal analysis, Validation, writing (review \& editing)

Stéphane Ory: Conceptualization, Supervision, Validation, writing (review \& editing)

Stéphane Gasman : Conceptualization, Supervision, Validation, Funding acquisition, Project administration, writing (original and review) 


\section{Somatostatin analogue pasireotide (SOM230) inhibits catecholamine secretion in human pheochromocytoma cells}

Laura Streit ${ }^{1}$, Sophie Moog ${ }^{1}$, Sylvain Hugel ${ }^{1}$, Marion Rame ${ }^{1}$, Emeline Tanguy ${ }^{1}$, Virginie Andry ${ }^{1,2}$, Herbert A. Schmid ${ }^{3}$, Laurent Brunaud ${ }^{4}$, Florence Bihain ${ }^{4}$, Claire Nominé-Criqui ${ }^{4}$, Yannick Goumon ${ }^{1,2}$, Stéphanie Lacomme ${ }^{5}$, Sandra Lomazzi ${ }^{5}$, Michel Vix ${ }^{6}$, Didier Mutter ${ }^{6}$, Nicolas Vitale ${ }^{1}$, Stéphane Ory ${ }^{1 \#}$ and Stéphane Gasman ${ }^{1 * \#}$

${ }^{1}$ Centre National de la Recherche Scientifique, Université de Strasbourg, Institut des Neurosciences Cellulaires et Intégratives, F-67000 Strasbourg, FRANCE

${ }^{2}$ SMPMS-INCI, Mass Spectrometry Facilities of the CNRS UPR3212, Centre National de la Recherche Scientifique, Université de Strasbourg, Institut des Neurosciences Cellulaires et Intégratives, F-67000 Strasbourg, FRANCE

${ }^{3}$ Novartis Pharmaceuticals, WSJ-103.5.10.1, CH-4002 Basel, SWITZERLAND

${ }^{4}$ Département de Chirurgie Viscérale, Métabolique et Cancérologique (CVMC), Unité médicochirurgicale de chirurgie métabolique, endocrinienne et thyrö̈dienne (UMET), Unité médicochirurgicale de chirurgie de l'obésité (UMCO), Université de Lorraine, CHRU NANCY, Hôpital Brabois adultes, F-54511 Vandœuvre-lès-Nancy, FRANCE

${ }^{5}$ Centre de Ressources Biologiques Lorrain, CHRU Nancy, Hôpitaux de Brabois, F-54511 Vandœuvre-lès-Nancy, FRANCE

${ }^{6}$ NHC Strasbourg, Service de Chirurgie Digestive et Endocrinienne des Hôpitaux Universitaires de Strasbourg, Hôpital Civil, F-67000 Strasbourg, FRANCE

\# S. Ory and S. Gasman contributed equally to this paper

*Corresponding author: Stéphane Gasman, address as above.

e-mail: gasman@inci-cnrs.unistra.fr 


\begin{abstract}
Increasingly common, neuroendocrine tumors (NETs) are regarded nowadays as neoplasms potentially causing debilitating symptoms and life-threatening medical conditions. Pheochromocytoma is a NET that develops from chromaffin cells of the adrenal medulla, and is responsible for an excessive secretion of catecholamines. Consequently, patients have an increased risk for clinical symptoms such as hypertension, elevated stroke risk and various cardiovascular complications. Somatostatin analogues are among the main anti-secretory medical drugs used in current clinical practice in patient with NETs. However, their impact on pheochromocytoma-associated catecholamine hypersecretion remains incompletely explored. This study investigated the potential efficacy of octreotide and pasireotide (SOM230) on human tumor cells directly cultured from freshly resected pheochromocytomas using an implemented catecholamine secretion measurement by carbon fiber amperometry. SOM230 treatment efficiently inhibited nicotine-induced catecholamine secretion both in bovine chromaffin cells and in human tumor cells whereas octreotide had no effect. Moreover, SOM230 specifically decreased the number of exocytic events by impairing the stimulation-evoked calcium influx as well as the nicotinic receptor-activated inward current in human pheochromocytoma cells. Altogether, our findings indicate that SOM230 acts as an inhibitor of catecholamine secretion through a mechanism involving the nicotinic receptor and might be considered as a potential anti-secretory treatment for patients with pheochromocytoma.
\end{abstract}

Key words: somatostatin analogues, pasireotide (SOM230), octreotide, neuroendocrine tumor, pheochromocytoma, exocytosis, secretion 


\section{INTRODUCTION}

Neuroendocrine tumors (NETs) are a heterogeneous group of neoplasms arising from hormone, amine and peptide secreting cells that are spread all over the body, and its incidence has constantly increased during the last decades. NETs are often associated with a deregulation of hormone secretion which can induce clinical complications [1-6].

Pheochromocytoma (Pheo) is a NET arising from chromaffin cells of the adrenal medulla, which store and then secrete catecholamines in the blood stream. While Pheos are rare, most of them are responsible for catecholamine hypersecretion that may lead to severe and potentially life-threatening clinical complications. Clinical symptoms in patients with Pheos are mainly related to catecholamine hypersecretion and include the classic triad of headaches, palpitations, and profuse sweating but also permanent or paroxysmal hypertension [7-9]. It has been also reported that Pheo can lead to severe acute cardiovascular complications including myocarditis, Takotsubo syndrome, as well as various forms of cardiomyopathies [10, 11]. Accordingly, a retrospective study has shown that patients with Pheo have a 14-fold higher rate of cardiovascular events than patients with essential hypertension [12]. Finally, it is interesting to note that approximately 1 Pheo is found every 2000 autopsies $(0.05 \%)$, a proportion significantly higher than the estimated prevalence of the general population suggesting a premature mortality caused by Pheo $[13,14]$.

Although currently controversial, the symptoms of patients with Pheo can be treated by preoperative antihypertensive medications such as $\alpha$ - and $\beta$-blockers or calcium channel blockers to counteract the negative effect of excessive catecholamine secretion during surgical resection [15]. In France, the most common antihypertensive treatments currently use are calcium channel blockers such as nicardipine $[16,17]$. However, to this date, no drug has been shown to directly and specifically prevent hypersecretion of tumor chromaffin cells. Interestingly, somatostatin analogues are currently among the most widely used drugs to treat the symptoms of different NETs, including excessive hormone secretion [18]. Octreotide and lanreotide were the two first-generation analogues tested and are still currently used in the treatment of gastroenteropancreatic NETs and acromegaly caused by a pituitary adenoma [19]. These analogues were reported to have a dual effect by decreasing both tumor cell proliferation 
and tumor hypersecretion $[18,20,21]$. In the early 2000s, a new generation of somatostatin analogues has emerged with the development of pasireotide (SOM230). While octreotide binds preferentially the somatostatin receptor SSR2, SOM230 is a multireceptor-targeted analogue with a 40-, 30- and 5-fold higher affinity than octreotide for somatostatin receptors SSR5, SSR1 and SSR3, respectively [22, 23]. For instance, SOM230 has been authorized for Cushing disease and acromegaly treatments [24, 25]. In vitro and in vivo data have also shown that this analog is able to effectively inhibit gastroenteropancreatic NETs secretion and improve symptoms in patients refractory to octreotide treatment $[20,26]$.

As somatostatin receptors are also expressed by Pheo [27, 28], the aim of the present work was to investigate whether somatostatin analogues impact catecholamine secretion of adrenal chromaffin cells in vitro and thus determine its potential to prevent catecholamine hypersecretion. Using carbon fiber amperometry, we have tested the effect of octreotide and SOM230 treatments on primary cultures of either bovine chromaffin cells or tumor cells directly cultured from freshly resected human Pheos and found that SOM230 has an effective anti-secretory effect. 


\section{MATERIALS AND METHODS}

\subsection{Materials}

Octreotide and pasireotide (SOM230) were obtained from Novartis, Basel, Switzerland. Analogues were dissolved in dimethyl sulfoxide (DMSO), and stock solutions at $10^{-2}$ or $10^{-3} \mathrm{M}$ were stored at $-20^{\circ} \mathrm{C}$ and protected from light exposure.

\subsection{Patient population}

The medical files of patients with Pheo in 2 French centers between 2017 and 2021 were retrospectively reviewed. We collected the following data: initial diagnosis, including a clinical examination looking for hormonal-related symptoms and biological analysis. As recommended by the Endocrine Society clinical practice guideline published in 2014 [29], Pheo genetic testing was proposed to identify germline mutations in the major susceptibility genes (SDHB, SDHC, SDHD, VHL, NF1, RET, TMEM127, MAX) using Sanger sequencing and multiplex ligationdependent probe amplification (MLPA). Then, as recommended in the consensus statement published in 2017 [30], next-generation-sequencing (NGS)-based diagnostic was carried out for more recent patients. Biological analysis comprised the measurement of metanephrine (MN) and normetanephrine (NMN) levels (in urine and/or plasma). When available, chromogranin A (CGA) measurements were also registered. Levels of free MN, NMN and CGA in plasma, as well as urinary levels of $\mathrm{MN}$ and $\mathrm{NMN}$ are presented as ratios normalized by the normal upper limits. Urinary or plasma MN and NMN levels reaching two-fold the upper limit of the normal range and/or CGA exceeding the upper limit of the normal range was defined as the threshold of abnormal hormonal secretion [7]. Catecholamine-producing phenotype of Pheo were categorized as previously described [31]: adrenergic (AD) phenotype, when MN content exceeded $10 \%$ of the combined MN and NMN contents, or noradrenergic (NAD) phenotype when MN content remained below $10 \%$ of the combined MN and NMN contents. Pathological evaluation was reviewed, including tumor size, Ki-67 result and the PASS (Pheochromocytoma of the Adrenal Gland Scaled Score) as previously described [32].

\subsection{Primary culture of chromaffin cells}

Bovine chromaffin cells were cultured as previously described [33]. Human tumor cells were cultured from freshly resected Pheos following surgery [34]. In the operating room and 
immediately after the resection, the adrenal gland was cut longitudinally in two parts. Roughly a $1 \mathrm{~cm}^{3}$ piece of tumor tissue was dissected and immediately plunged into ice cold transport medium $\left(\mathrm{Ca}^{2+}\right.$ - and $\mathrm{Mg}^{2+}$-free Hank's Balanced Salt Solution (CMF HBSS, Sigma) supplemented with $0.2 \%$ Fetal Bovine Serum (FBS, Gibco) and 1\% penicillin/streptomycin (Sigma) or MACS Medium Tissue Storage solution (Miltenyi Biotec). Up to 3 hours after resection, the tumor sample was minced into $1 \mathrm{~mm}^{3}$ pieces in a dish containing CMF HBSS. Chunks were collected, centrifuged at $250 \mathrm{~g}$ for $5 \mathrm{~min}$ at room temperature and the pellet resuspended in $15 \mathrm{~mL}$ of complete medium (RPMI 1640 GlutaMAX $^{\mathrm{TM}}$ (Gibco), 15\% FBS, 1\% penicillin/streptomycin). Red blood cells, debris and fat were separated from minced tissue by sedimentation for $15 \mathrm{~min}$ at room temperature. The supernatant was removed and $15 \mathrm{~mL}$ of complete medium were added to the pellet before centrifugation at $250 \mathrm{~g}$ for $5 \mathrm{~min}$. Tumor pieces were resuspended in HBSS (in 10 times the tissue volume), containing $1.5 \mathrm{mg} / \mathrm{mL}$ of collagenase B (Roche) and $1 \mathrm{mg} / \mathrm{mL}$ of the protease dispase II (Gibco) and gently rocked for $45 \mathrm{~min}$ at $37^{\circ} \mathrm{C} .5 \mathrm{~min}$ before the end of protease digestion, $0.1 \mathrm{mg} / \mathrm{mL}$ DNase I (Roche) was added to remove potential DNA clumps. Samples were left for a few minutes to sediment at room temperature and supernatant recovered (fraction 1). The pellet was resuspended in $5 \mathrm{~mL}$ of CMF HBSS and triturated for a couple of minutes to dislodge tumor cells from chunks. The remaining pieces were left few minutes to sediment and the supernatant recovered (fraction 2). Both fractions were centrifuged at $800 \mathrm{~g}$ for $5 \mathrm{~min}$ at room temperature. Cell pellets were resuspended in $2 \mathrm{~mL}$ of CMF HBSS. $4 \mathrm{~mL}$ of Red Blood Cell Lysis Buffer (Roche) were added before being gently rocked for $10 \mathrm{~min}$ at room temperature. The fractions were centrifuged at $500 \mathrm{~g}$ for $5 \mathrm{~min}$ and resuspended into complete medium. Cell viability and density were estimated under a microscope and $300 \mu \mathrm{L}$ of cell suspension were seeded into type I collagen (Corning)-coated $35 \mathrm{~mm}$ dishes (MatTek) for amperometry or polylysine (Sigma)-coated glass coverslips for calcium imaging and electrophysiology experiments. Cells were left to adhere overnight at $37^{\circ} \mathrm{C}$ in an incubator with water-saturated and $5 \% \mathrm{CO}_{2}$ atmosphere. $2 \mathrm{~mL}$ of complete RPMI were added the following day and cells were used within two days.

\subsection{Catecholamine secretion assay}

Assays were performed as previously described [33]. Briefly, bovine chromaffin cells were seeded in 96 well plates (Thermo Fisher Scientific) at a density of 250,000 cells per well and were maintained in culture for 48 to 72 hours before experiments. Cells were washed 3 times for $7 \mathrm{~min}$ with $200 \mu \mathrm{L}$ of Locke's solution $(140 \mathrm{mM} \mathrm{NaCl}, 4.7 \mathrm{mM} \mathrm{KCl}, 2.5 \mathrm{mM} \mathrm{CaCl} 2,1.2$ $\mathrm{mM} \mathrm{KH}_{2} \mathrm{PO}_{4}, 1.2 \mathrm{mM} \mathrm{MgSO}_{4}, 11 \mathrm{mM}$ glucose, $0.01 \mathrm{mM}$ EDTA, $0.56 \mathrm{mM}$ ascorbic acid and 
$15 \mathrm{mM}$ HEPES, $\mathrm{pH} 7.5$ ) at $37^{\circ} \mathrm{C}$ and stimulated for $10 \mathrm{~min}$ with $50 \mu \mathrm{L}$ of an high $\mathrm{K}^{+}$solution (Locke's solution containing $59 \mathrm{mM} \mathrm{KCl,} \mathrm{pH} \mathrm{7.2)} \mathrm{or} 10 \mu \mathrm{M}$ nicotine (Sigma) with or without SOM230 or octreotide. Basal secretion was obtained by maintaining cells in Locke's solution for $10 \mathrm{~min}$. The secretion was stopped by placing cells at $4^{\circ} \mathrm{C}$ and supernatants were immediately collected. Cells were lysed with $200 \mu \mathrm{L}$ of Locke's solution containing $1 \%$ Triton $\mathrm{X}-100$ (Sigma) for $3 \mathrm{~min}$ at $37^{\circ} \mathrm{C}$. The plate was then centrifuged at 3,000 $\mathrm{g}$ for $10 \mathrm{~min}$ at room temperature. $20 \mu \mathrm{L}$ of each sample were transferred to a black 96-well plate (Thermo Fisher Scientific). $150 \mu \mathrm{L}$ of $\mathrm{CH}_{3} \mathrm{COOH}\left(1 \mathrm{M}, \mathrm{pH}\right.$ ) and $15 \mu \mathrm{L}$ of $\mathrm{K}_{3} \mathrm{Fe}(\mathrm{CN})_{6}(0.25 \%)$ were added to oxidize the noradrenaline and adrenaline to noradrenochrome and adrenochrome, respectively. Addition of $50 \mu \mathrm{L}$ of $\mathrm{NaOH}(5 \mathrm{M})$ containing ascorbic acid $(0.3 \mathrm{mg} / \mathrm{mL})$ transformed aminochromes to fluorescent noradrenolutine and adrenolutine. Fluorescence was measured ( $\lambda_{\text {excitation }}: 430 \mathrm{~nm}, \lambda_{\text {emission: }} 520 \mathrm{~nm}$ ) with a spectrofluorometer (Mithras LB 940, Berthold). Amounts of secreted catecholamines are expressed as percent of total catecholamines. Data are representative of at least 3 independent cultures and each measurement was realized in triplicate. The sigmoid curve in Figure 1B have been fitted using the 4-parameter logistic regression curve method (Sigma Plot).

\subsection{Mass Spectrometry}

Preparation and derivation: bovine chromaffin cells were stimulated as described above in 2.4. The secretion medium was then recovered and $50 \mu \mathrm{L}$ of $\mathrm{H}_{2} \mathrm{O}$ containing $0.1 \mathrm{mM}$ ascorbic acid was added to the well containing chromaffin cells. Cells were detached mechanically and the cell lysates were sonicated (4 x $10 \mathrm{sec}, 100 \mathrm{~W}$; Model 505 Sonic Dismembrator; Fisher Scientific). After centrifugation $\left(20,000 \mathrm{~g}, 30 \mathrm{~min}, 4^{\circ} \mathrm{C}\right)$, supernatants were collected.

$20 \mu \mathrm{L}$ of the cell extract or $20 \mu \mathrm{L}$ of the secretion medium were mixed with $30 \mu \mathrm{L}$ of borate buffer, $10 \mu \mathrm{L}$ AccQtag Ultra reagent (AccQ-Tag Ultra derivatization kit, Waters, Guyancourt) and $10 \mu \mathrm{L}$ of internal standards containing 20 pmoles of D4-Dopamine, D6-Adrenaline and C6Noradrenaline in $0.1 \mathrm{mM}$ ascorbic acid. The mixture was incubated $10 \mathrm{~min}$ at $55^{\circ} \mathrm{C}$ under agitation. Then, $280 \mu \mathrm{L}$ of acetonitrile was added in order to precipitate proteins, and samples were centrifuged at $20,000 \mathrm{~g}$ during $15 \mathrm{~min}$ at $4^{\circ} \mathrm{C}$. The resulting supernatants were dried under vacuum and suspended in $20 \mu \mathrm{L}$ of $\mathrm{H}_{2} \mathrm{O}$ containing $0.1 \%$ formic acid (v/v). Finally, $5 \mu \mathrm{L}$ of the resulting extracts were analyzed by LC-MS/MS (see below). Samples were loaded into reverse phase Zorbax column (1SB-C18, \#863600-902; $1 \mathrm{~mm} \mathrm{x} 150 \mathrm{~mm}, 3.5 \mu \mathrm{m}$, Agilent Technologies). 
LC-MS/MS conditions: a LC-MS/MS approach was used to quantify the presence of dopamine, adrenaline, and noradrenaline using the multiple reaction monitoring mode (MRM). Analyses were performed on a Dionex Ultimate 3000 HPLC system (Thermo Scientific) coupled with an Endura triple quadrupole mass spectrometer (Thermo Electron). The system was controlled by Xcalibur v. 2.0 software (Thermo Electron).

Elution of the compounds was performed at a flow rate of $90 \mu \mathrm{L} / \mathrm{min}$, at $40^{\circ} \mathrm{C}$, according to the gradient detailed in Supplementary Table 1. Buffer A corresponded to $\mathrm{H}_{2} \mathrm{O}$ 98.9\%/ACN $1 \% /$ formic acid $0.1 \%(\mathrm{v} / \mathrm{v} / \mathrm{v})$, whereas buffer B was ACN $99.9 \%$ / formic acid $0.1 \%(\mathrm{v} / \mathrm{v})$. The MRM mode was used to identify and quantify target molecules according to the instrument settings and target compounds molecular signatures detailed in Supplementary Table 2. The selection of the monitored transitions and the optimization of the collision energy (CE) were manually determined. The identification of the compounds was based on precursor ion, selective fragment ions and retention times obtained for dopamine, adrenaline, and noradrenaline and their corresponding internal standards. Amounts of neurotransmitters were quantified according to the isotopic dilution method [35].

\subsection{Carbon fiber amperometry}

Chromaffin cells were washed with Locke's solution (without ascorbic acid) and processed for catecholamine release measurements by amperometry as previously described [36, 37]. A carbon fiber electrode of $5 \mu \mathrm{m}$ diameter (ALA Scientific Instruments) was held at a potential of $+650 \mathrm{mV}$ compared with the reference electrode $(\mathrm{Ag} / \mathrm{AgCl})$ and approached close to one cell. Secretion of catecholamines was induced by a 10 s pressure ejection of a $100 \mu \mathrm{M}$ nicotine (Sigma) solution from a micropipette positioned $10 \mu \mathrm{m}$ from the cell and recorded over $60 \mathrm{~s}$. The somatostatin analogue (octreotide or SOM230) was added either in the stimulation pipette or directly in the incubation medium. The amperometric recordings were performed with an AMU130 amplifier (Radiometer Analytical), calibrated at $5 \mathrm{kHz}$, and digitally low-pass filtered at $1 \mathrm{kHz}$. Analysis of the amperometric recordings was performed as previously described with a macro (laboratory of Dr. R. Borges; http://webpages.ull.es/users/rborges/) written for Igor software (WaveMetrics), allowing automatic spike detection and extraction of spike parameters [38]. The spike parameters analysis was restricted to spikes with amplitudes higher than $5 \mathrm{pA}$, which were considered as exocytic events. All spikes identified by the program were visually inspected. Overlapping spikes and spikes with aberrant shapes were discarded for parameters analysis. Quantal size (spike charge, Q) of each individual spike was measured by calculating the spike area above the baseline. Spike area is defined as the time integral of each transient 
current, Imax as the height of each spike, half-width as the width of each spike at half its height $\left(\mathrm{T}_{1 / 2}\right)$ and $\mathrm{T}_{\text {peak }}$ as the spike rise time (Figure $2 \mathrm{C}$ ).

\subsection{Intracellular calcium imaging}

Changes in the intracellular $\mathrm{Ca}^{2+}$ concentration were detected by the ratiometric fluorescent probe Fura-2. Cells were loaded during a 1 hour incubation with $2 \mu \mathrm{M}$ of the cell-permeant precursor Fura-2 acetoxymethyl ester (Fura-2AM; Molecular Probes) and $0.001 \%$ (w/v) pluronic acid (Molecular Probes). The recording saline solution contained $135 \mathrm{mM} \mathrm{NaCl}, 5$ $\mathrm{mM} \mathrm{KCl}, 2 \mathrm{mM} \mathrm{CaCl} 2,2 \mathrm{mM} \mathrm{MgCl} 2,10 \mathrm{mM}$ glucose and $10 \mathrm{mM}$ HEPES, $\mathrm{pH}$ 7.4. Fluorescence measurements were performed on an inverted microscope (Axiovert 35; Zeiss) with an oil immersion 40 Nikon objective (Fluor 40, NA 1.30) and a cooled CCD camera (CoolSnap HQ; Photometrics). The Imaging Workbench 4.0 software (Axon Instruments) was used for image acquisition. Fluorescence was excited alternately at 350 and $380 \mathrm{~nm}$ with a Lambda-10 filter wheel (Sutter Instruments), and emitted light was collected above $520 \mathrm{~nm}$. Pairs of images were acquired every $2 \mathrm{~s}$. Intracellular calcium level is expressed throughout as the fluorescence ratio $\mathrm{F}_{350} / \mathrm{F}_{380}$, calculated after background subtraction. Experiments were performed at $34^{\circ} \mathrm{C}$. During calcium measurements, cells were continuously perfused with saline solution: the whole dish by a bath perfusion of control medium and the recorded field by a single-tip multichannel gravity-fed system, allowing switching between various solutions. Analysis was performed using Clampfit 10.2 (MDS Analytical Technologies). Responses induced by $15 \mu \mathrm{M}$ nicotine in presence of SOM230 were normalized with respect to the average of the previous and subsequent responses induced by $15 \mu \mathrm{M}$ nicotine alone.

\subsection{Electrophysiological recordings}

Whole-cell patch-clamp recordings were performed with an Axopatch 200A amplifier (Axon Instruments) and low resistance (3- $4 \mathrm{M} \Omega$ ) electrodes. The final series resistance during electrophysiological recordings was between 5 and $15 \mathrm{M} \Omega$. Membrane currents were recorded under voltage-clamp at a steady holding potential of $-60 \mathrm{mV}$. The recording saline solution was the same as for calcium imaging experiments (see above). The culture dish was continuously perfused with extracellular solution at a rate of $3 \mathrm{~mL} \cdot \mathrm{min}^{-1}$. Recording electrodes were filled with: $140 \mathrm{mM} \mathrm{KCl}, 2 \mathrm{mM} \mathrm{MgCl} 2,10 \mathrm{mM}$ HEPES, 2 mM MgATP, pH 7.3. $1 \mathrm{mM}$ QX314 (Alomone Labs) was added to the intrapipette solution to prevent spiking of the recorded cell. Experiments were performed at room temperature $\left(20-22^{\circ} \mathrm{C}\right)$. The different substances were applied or coapplied locally by means of a U- tube allowing a relatively fast solution exchange 
around the cell (<50 ms). Signals were low-pass filtered at $5 \mathrm{kHz}$, sampled at $20 \mathrm{kHz}$, digitized using a BNC-2110 data acquisition card (National Instruments) and acquired with the Strathclyde electrophysiology software (WinWCP, John Dempster, University of Strathclyde). Analysis was performed using Clampfit 10.2 (MDS Analytical Technologies). Responses induced by $15 \mu \mathrm{M}$ nicotine in presence of SOM230 were normalized with respect to the average of the previous and subsequent responses induced by $15 \mu \mathrm{M}$ nicotine alone.

\subsection{Statistical analysis}

Statistical analyses were performed using SigmaPlot 13.0 (Ritme). One way ANOVA followed by Dunnett test were performed to assess the difference between multiple groups when data followed normal distribution and equal variance. If normality or equal variance failed, significance was estimated by non-parametric tests. Wilcoxon Rank Sum test or Mann-Whitney Rank Sum test was used for comparison between two groups and multiple comparisons Kruskal-Wallis One Way Analysis of Variance on Ranks followed by Dunn's test were performed to assess the difference between multiple groups. A p value $<0.05$ was considered to be significant for all tests. 


\section{RESULTS}

\subsection{Effect of octreotide and pasireotide on bovine chromaffin cells secretion}

We first analyzed the potential effect of the first-generation somatostatin analogue octreotide and the next-generation somatostatin analogue pasireotide (SOM230) on catecholamine secretion from primary culture of bovine chromaffin cells. To analyze the global catecholamine release, we used an assay based on the oxidation of catecholamines into fluorescent aminolutin [33]. Secretion was evoked either by $10 \mu \mathrm{M}$ nicotine or by a high $\mathrm{K}^{+}$depolarizing solution (59 $\mathrm{mM})$. As shown in Figure 1A, increasing concentration of octreotide did not affect catecholamine secretion regardless of the stimulus type. On contrary, SOM230 treatment triggered a significant dose-dependent inhibition of the nicotine-induced catecholamine secretion $\left(\mathrm{IC}_{50}=2.64 \mu \mathrm{M}\right.$ and maximum efficacy $=77 \%$ inhibition $)$, whereas no effect was observed on $\mathrm{K}^{+}$-evoked secretion (Figure 1B). At higher concentration, SOM230 inhibited catecholamine release up to $81.0 \% \pm 2.4 \%$ (Figure 1B). In agreement with previous studies $[39,40]$, we also observed in our experimental conditions that somatostatin (SS14) inhibited catecholamine secretion in a concentration range similar to SOM230 (not shown).

A

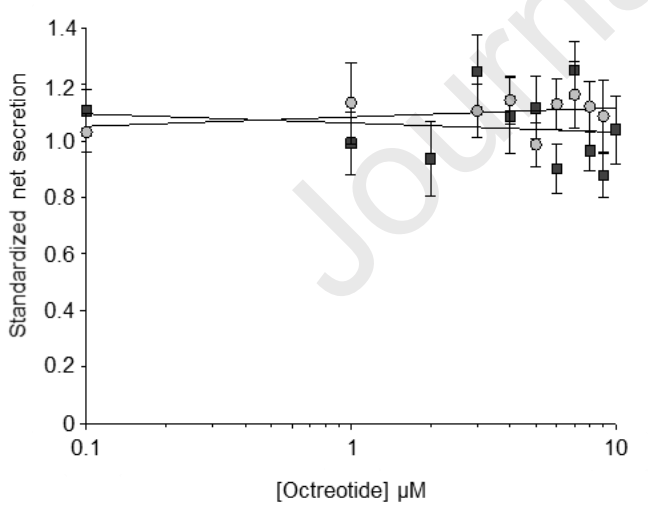

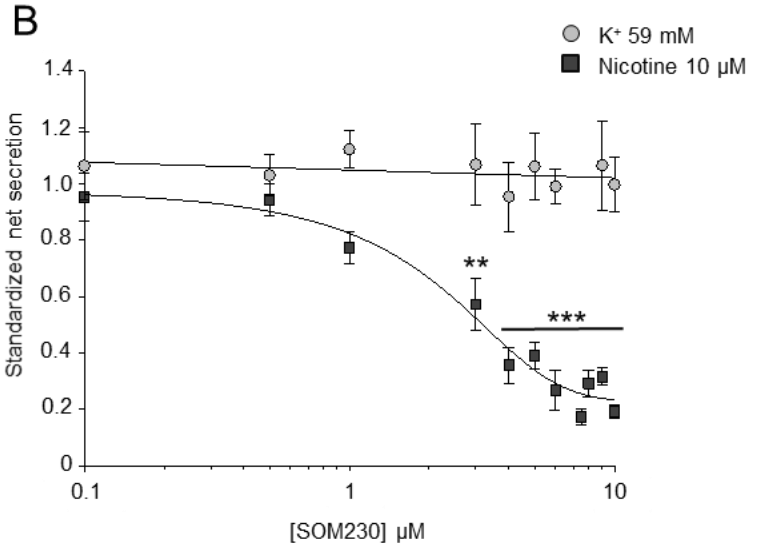

C
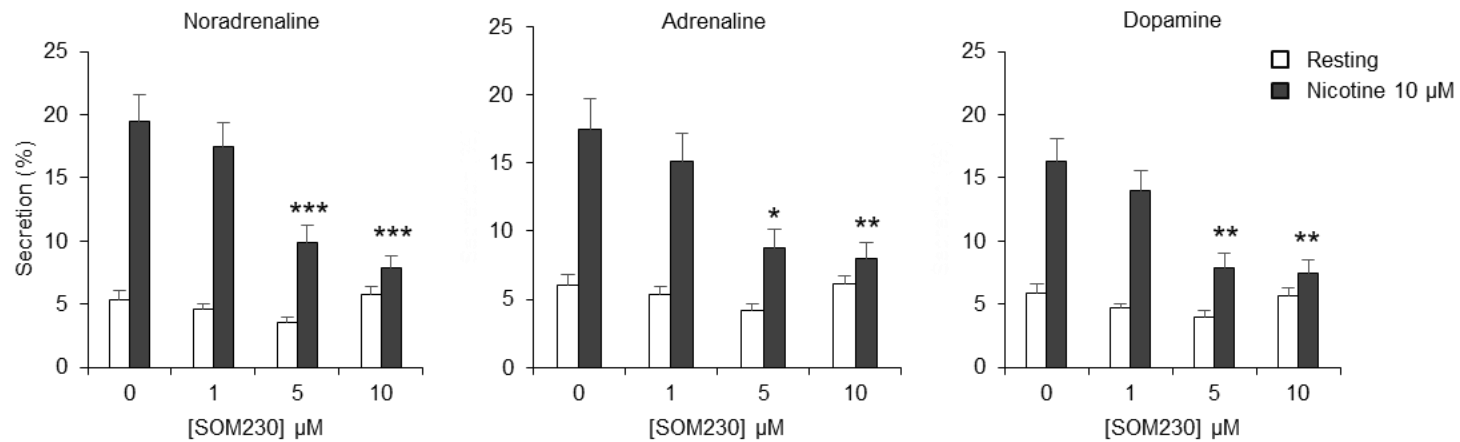
Figure 1. The somatostatin analogue pasireotide (SOM230) specifically inhibits catecholamine secretion from bovine chromaffin cells.

Bovine chromaffin cells were stimulated with $10 \mu \mathrm{M}$ nicotine or with a high $\mathrm{K}^{+}$depolarizing solution $(59 \mathrm{mM})$ for $10 \mathrm{~min}$ in the presence of the indicated concentrations of octreotide (a) or SOM230 (b). Catecholamine release was quantified using an adrenolutine fluorescent assay (a, b) or mass spectrometry (c). For adrenolutine assay, basal release was subtracted to obtain the net catecholamine secretion and for each concentration of analogues, secretion was normalized to control secretion (untreated cells) which was fixed to 1 . The proportion of catecholamines secreted in resting and stimulated conditions are indicated in Supplementary Figures 1A and B. Data are given as the mean values \pm SEM obtained from different cell cultures $(n \geq 3)$.

${ }^{*} \mathrm{p}<0.05, * * \mathrm{p}<0.01, * * * \mathrm{p}<0.001$ compared to control; Kruskal-Wallis One Way Analysis of Variance on Ranks followed by Dunn's test or One Way ANOVA followed by Dunnett's test.

To confirm that SOM230 inhibits secretagogue-evoked catecholamine release and to check whether the secretion of different catecholamines is equally affected, we quantified noradrenaline, adrenaline and dopamine release using mass spectrometry. As shown in Figure 1C, SOM230 similarly inhibited noradrenaline, adrenaline and dopamine secretion. In control experiments, we have shown that $10 \mu \mathrm{M}$ octreotide does not modify the secretion of any of the catecholamines (Supplementary Figure 1C).

To better investigate the effect of SOM230 on secretion, we next recorded catecholamine release by carbon fiber amperometry (Figure 2). More sensitive than the adrenolutine assay, carbon fiber amperometry is an electrochemical method that allows to calculate frequency, quantal size and kinetics of individual exocytic events from single cells [41, 42]. Cultured bovine chromaffin cells were stimulated by a puff application using a stimulation pipette containing $100 \mu \mathrm{M}$ nicotine, with or without the indicated concentration of SOM230. As illustrated by the representative amperometric traces in Figure 2A, the most striking effect of SOM230 treatment is a reduction in the number of amperometric spikes. Indeed, increasing concentrations of SOM230 reduced substantially the spike number per cell (reduction from 76 to $82 \%$ ) indicating a strong decrease of exocytic events (Figure $2 \mathrm{~B}$ and Table 1). These results clearly demonstrated that SOM230 treatment drastically inhibits exocytosis leading to a large reduction of catecholamine release.

Each individual spike represents a single granule fusion event and is composed of a rapid rise corresponding to the quick release of a high concentration of catecholamine through a fusion pore as it dilates, followed by a slower decay representing the subsequent diffusion of molecules from the release site to the electrode surface. Therefore, analyzing the individual amperometric spike provided valuable dynamic information on the remaining exocytic process. The surface area or quantal size $(\mathrm{Q})$ is proportional to the amount of catecholamines released per event, the 
spike amplitude value (Imax) reflects the maximal flux of catecholamines, whereas the halfwidth $\left(T_{1 / 2}\right)$ and the time to peak $\left(T_{\text {peak }}\right)$ reflect the duration of exocytotic events and the kinetics of the fusion pore expansion, respectively (Figure 2C). The spike parameters means for each SOM230 concentration are listed in Table 1 . From $1 \mu \mathrm{M}$ concentration in the stimulation pipette, SOM230 reduced the spike amplitude with or without reducing the quantal size (Figure 2D, E, Table 1). This effect on quantal size may depend on the capacity of SOM230 to change the spike kinetics and duration as a concomitant increase of $T_{1 / 2}$ and $T_{\text {peak }}$ has been observed only at the concentration of 1 and $10 \mu \mathrm{M}$ (Table 1). Accordingly, superimposing the average shape of spikes for each SOM230 treatment conditions revealed that the spike height is progressively decreasing upon increasing concentration of SOM230 with a mild shift of spike kinetics for 1 and $10 \mu \mathrm{M}$ SOM230 treatment (Figure 2F). Altogether, the amperometric spike analyses suggest that SOM230 treatment might also affect the fusion pore formation/expansion/closure of the residual exocytic events or the granule catecholamine content. 
A

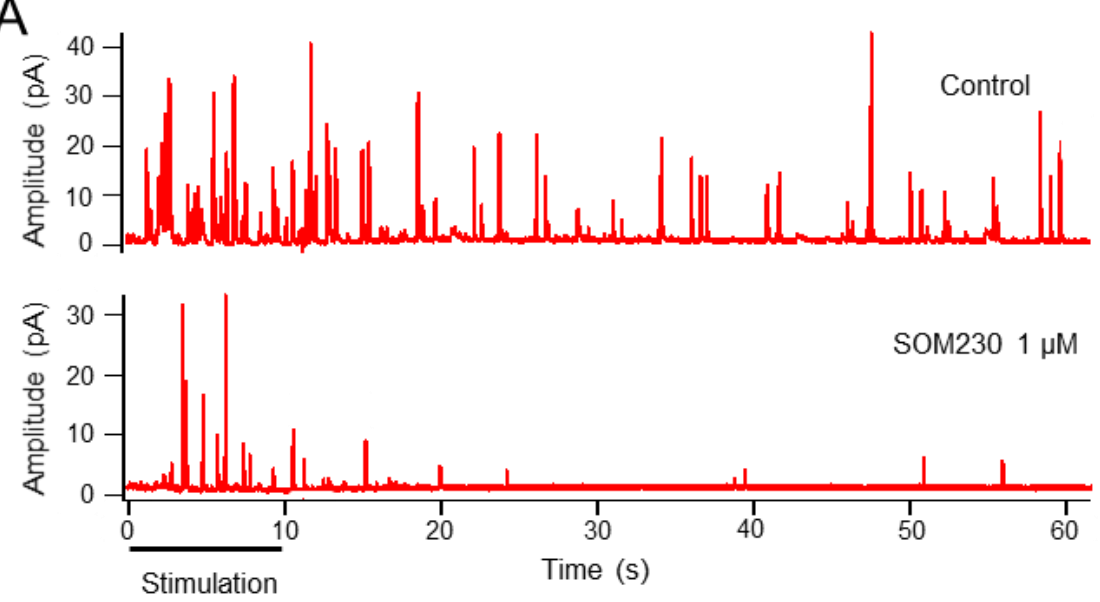

C

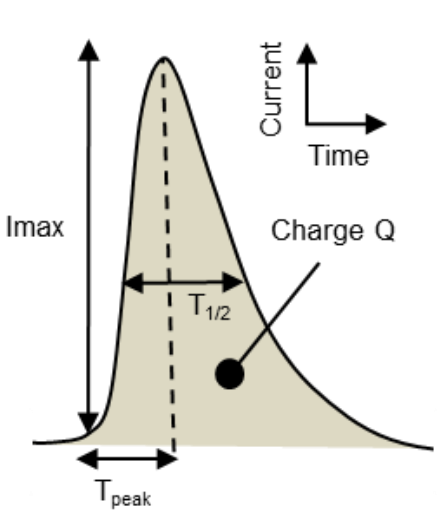

$\mathrm{F}$

[SOM230] $\mu \mathrm{M}$

G
B

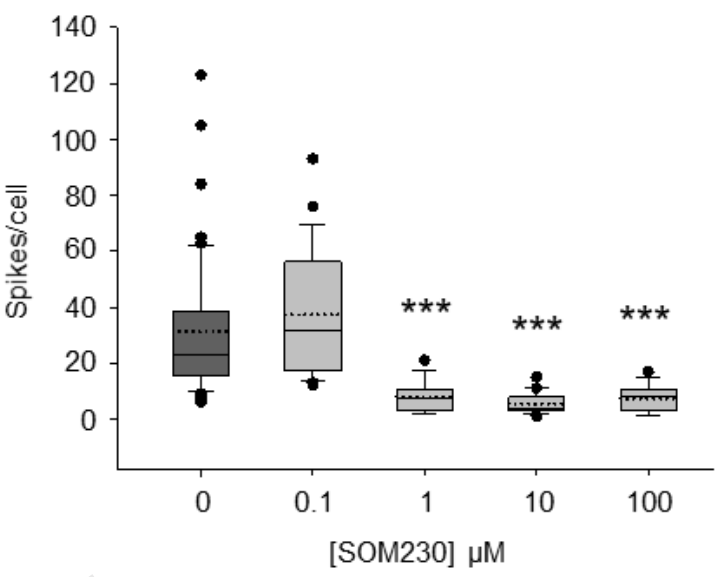

E

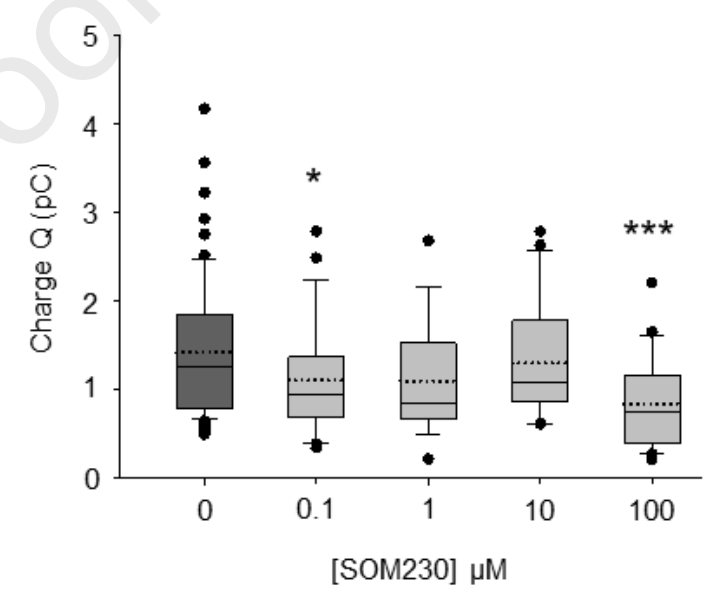

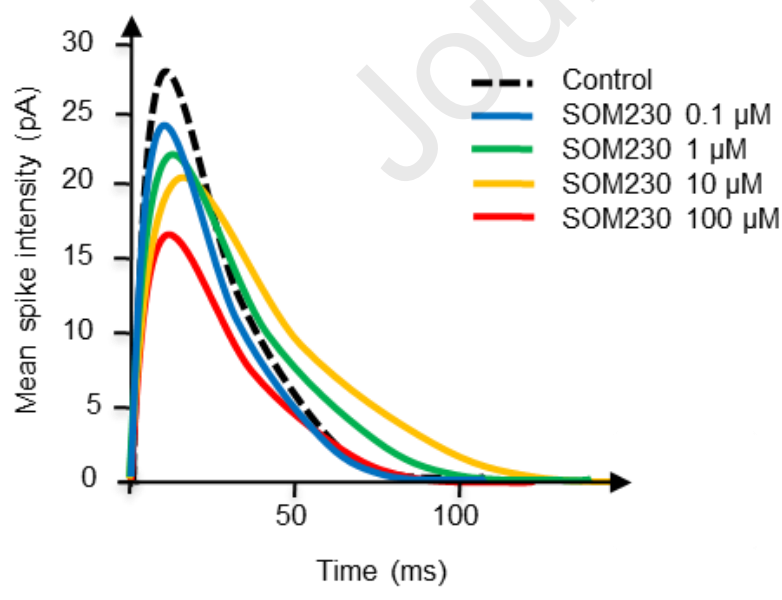

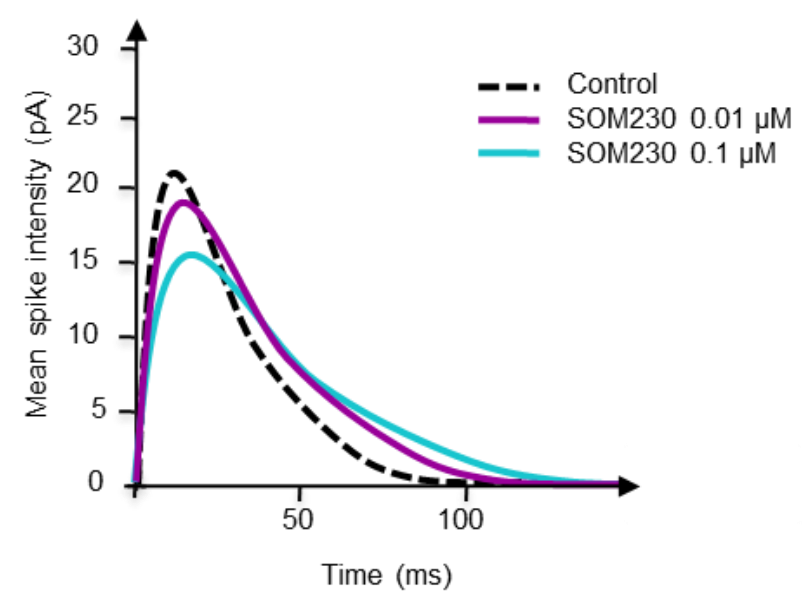

Figure 2. SOM230 affects different parameters of individual exocytotic events from single adrenal bovine chromaffin cells.

Single bovine chromaffin cells were stimulated with a local application of $100 \mu \mathrm{M}$ nicotine for $10 \mathrm{~s}$ and catecholamine secretion was monitored using carbon fiber amperometry. (a) Example of a typical amperometric recording obtained from an untreated cell (control) or a cell treated with $1 \mu$ M SOM 230 . (b) Box-and-whisker diagrams illustrating the number of amperometric spikes per cell. Each plot represents the 1st quartile (bottom line), the median (line in the box), the mean (dotted line in the box) and the third quartile (upper line). Whiskers correspond to the 5th (bottom) and the 95th (top) percentile 
and black dots represent outlier observations; *** $\mathrm{p}<0.001$ compared to control; Mann Whitney Rank Sum test. (c) Scheme of a spike representing a single granule fusion event and parameters that can be evaluated from each individual spike. (d, e) Increasing concentrations of SOM230 significantly affects the spike amplitude (Imax; (d)) and the quantal size (Charge Q; (e)); ${ }^{*} \mathrm{p}<0.05, * * \mathrm{p}<0.01, * * * \mathrm{p}<0.001$ compared to control; Mann Whitney Rank Sum test. (f) The superimposition of average spikes for each condition illustrates the effect on the spike shape of SOM230 when applied through the stimulation pipette. All the average amperometric data are detailed in Table 1.

Puff application of SOM230 close to single recorded cells is likely to misjudge the effective inhibiting dose of SOM230 because of the rapid dilution of the SOM230 solution in the cell incubation medium. Therefore, we also tested different SOM230 concentrations directly in the bath (Supplementary Figure 2). Under those conditions, treatment of cells with 0.01 and 0.1 $\mu \mathrm{M}$ SOM230 significantly inhibits the number of exocytic events by around 20 and 60\%, respectively. However, the residual spike amplitude was inhibited by around $30 \%$ only at 0.1 $\mu \mathrm{M}$, whereas quantal size was not significantly affected most likely due to an increase of $T_{1 / 2}$ and $T_{p e a k}$. These results indicate that SOM230 starts to significantly affect the exocytic process from $0.1 \mu \mathrm{M}$ and above.

\subsection{Effect of SOM230 treatment on catecholamine secretion of human pheochromocytoma cells}

The ability of SOM230 to also inhibit catecholamine secretion of human pheochromocytoma (Pheo) cells was the next important point we decided to address. Ten patients (6 females and 4 males, mean age of $62 \pm 10$ years) with histologically confirmed Pheo were included in this study (Table 2). Seven patients $(70 \%)$ were diagnosed with hormonal-related symptoms whereas all of them presented abnormal hormonal secretion (100\%). All were considered to have an adrenergic phenotype although three had excess normetanephrines. Two out of 10 patients $(20 \%)$ were diagnosed with a neurofibromatosis type 1 and one had a confirmed sporadic disease while the genotype of the 7 other patients was not known yet. The mean tumor size was $4.3 \mathrm{~cm}$ (range 1.8-7.0 cm). Other pathological characteristics are detailed in Table 2.

Catecholamine secretion analysis by carbon fiber amperometry was performed on tumor cells directly cultured from 8 of these freshly resected human Pheos. Four patient's cultures have been treated with SOM230 present in the stimulation pipette (patients 1 to 4 ), whereas the 4 others cultures have been treated with SOM230 directly added to the cell culture medium with lower SOM230 concentrations (patients 5 to 8). One to three different concentrations have been 
tested per patient depending on the culture viability over time and on the amount of material. All the amperometric parameters measured on human Pheo cells are summarized in Table 3.

Figure 3A shows representative amperometric traces recorded from untreated human Pheo cells (control) or from Pheo cells treated with $1 \mu \mathrm{M}$ SOM230 in stimulation pipette (left) or with 0.1 $\mu \mathrm{M}$ SOM230 in cell culture medium (right). From these recordings it is noticed that, as observed in bovine chromaffin cells, SOM230 treatment drastically reduced the number of spikes. Figure 3B illustrates the variation of the total amount of spikes per cell for each patient. Importantly, all patients were sensitive to SOM230 showing a significant decrease of exocytic events. Furthermore, the inhibitory effect of SOM230 on catecholamine release was dosedependent in all the cases, when different concentrations of SOM230 were tested on cells from the same patient. Of note, the inhibitory effect of SOM230 on catecholamine secretion appears more potent when it is present in the cell medium than when it is added to the pipette, because of the rapid dilution of SOM230 resulting from this type of application. Indeed, when present in the cell medium, SOM230 inhibits catecholamine secretion from $0.1 \mu \mathrm{M}$ (patients 5, 6, 7 and 8 with inhibition by around $88 \%, 56 \%, 63 \%$ and $42 \%$, respectively), a concentration that corresponds more or less to a puff of $1 \mu \mathrm{M}$ through the stimulation pipette. Accordingly, $1 \mu \mathrm{M}$ SOM230 treatment of Pheo cells through the stimulation pipette led to a significant inhibition of the number of spikes by around $43 \%$ (patient 3) and 61\% (patient 4).

Next we analyzed the dynamic parameters of the residual spikes upon treatment with different concentrations of SOM230. Figure 3C shows the average shape of spikes for each patient. Spike amplitude was reduced in $80 \%$ of patients' Pheo cells (ranging from 15 to $40 \%$ inhibition depending on SOM230 concentration) either alone (patients 4, 6 and 8) or associated with a decrease of the quantal size (patients 1 and 5) or with an increase of the kinetic and the duration of the exocytic events (patients 2 and 7). No significant changes have been observed for patient 3. These data tend to indicate that the residual exocytic events might be differentially affected from one patient to another.

Note that when octreotide treatment was tested on tumor cells from patient 2 at the highest dose of SOM230 (100 $\mu \mathrm{M}$; Supplementary Figure 3), only a modest decrease of the spike amplitude (around 15\%) was observed, whereas the number of exocytic events and the spike parameters 
remained unchanged. These data support a lack of effect of octreotide on catecholamine secretion from human Pheo cells and validate the specificity of the effect of SOM230.
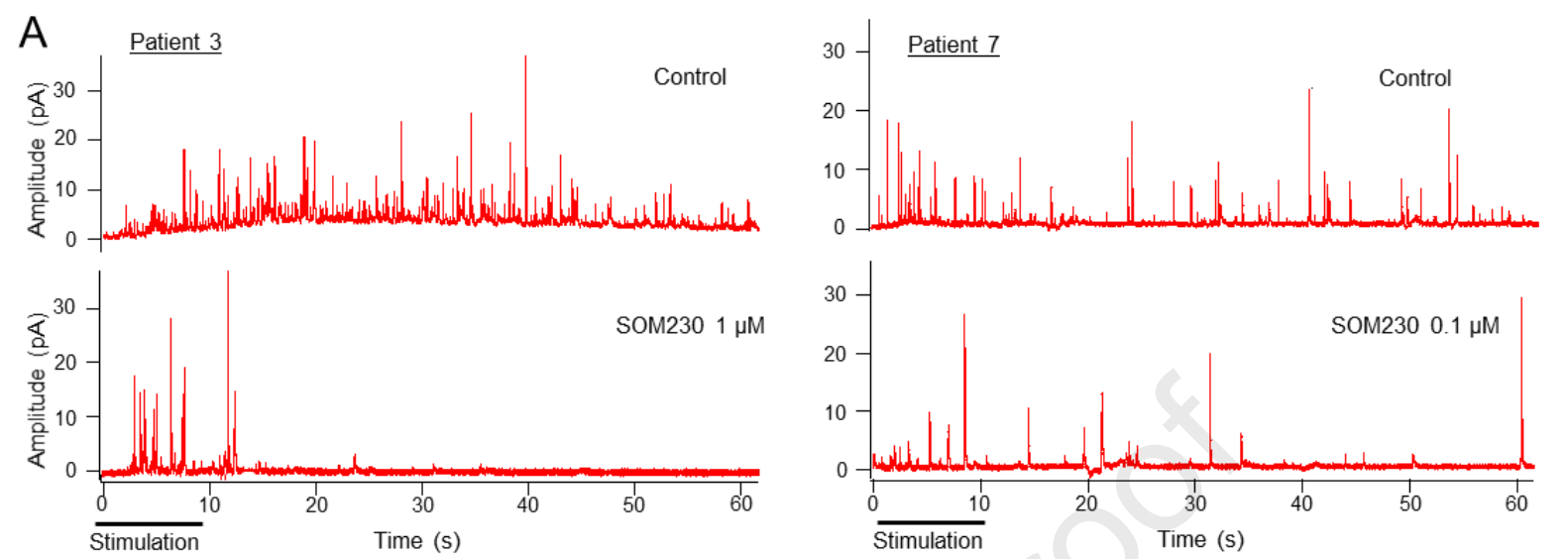

$\mathrm{B}$
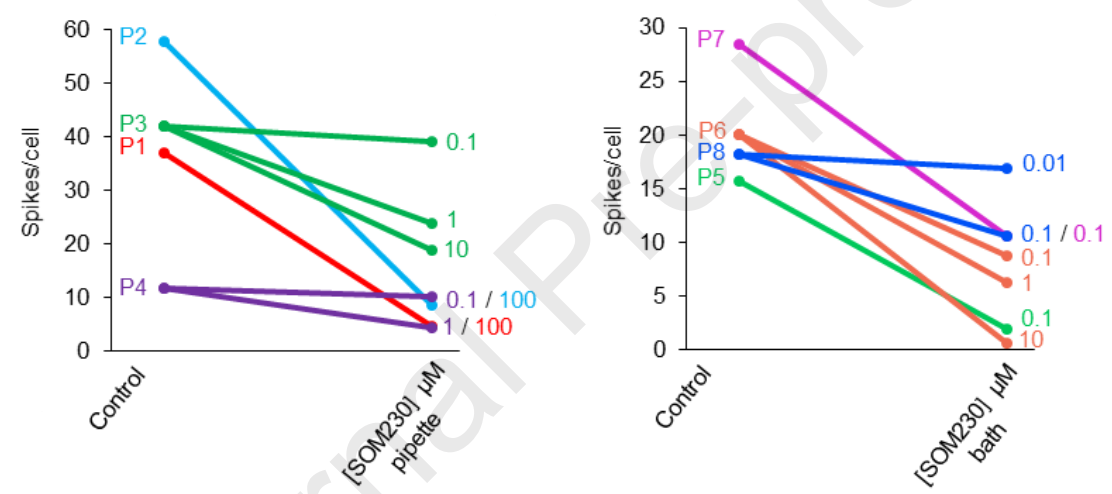

C

$\underline{\text { SOM230 in pipette }}$

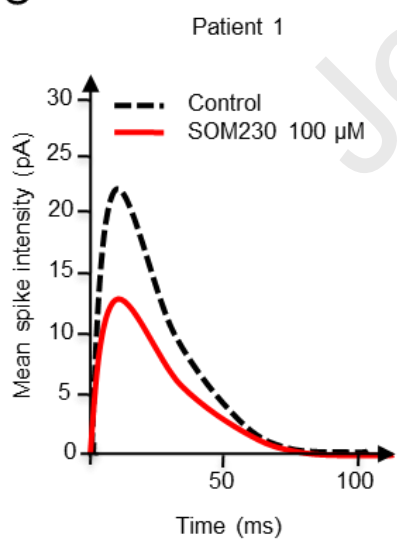

Patient 5

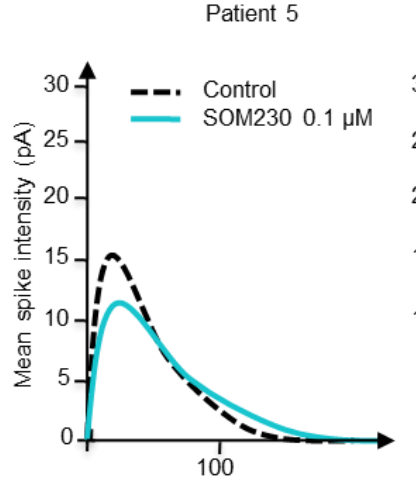

Time (ms)
Patient 2

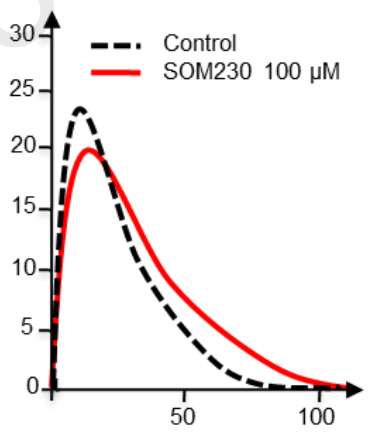

SOM230 in bath

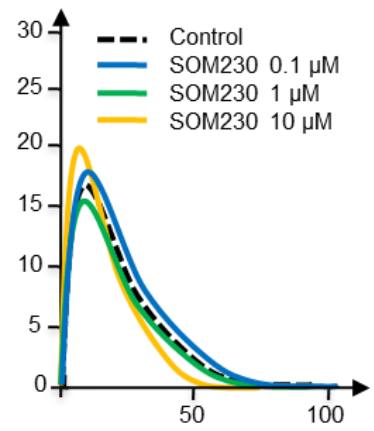

Patient 7

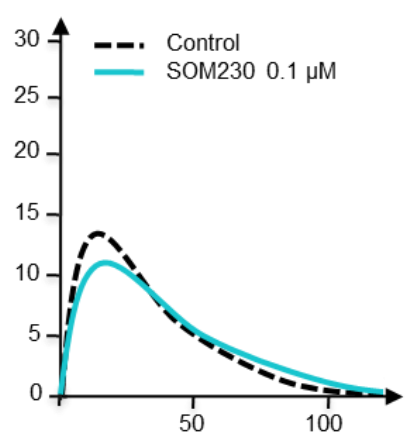


Figure 3. SOM230 inhibits the secretion of human pheochromocytoma cells.

Single human pheochromocytoma cells were stimulated with a local application of $100 \mu \mathrm{M}$ nicotine for $10 \mathrm{~s}$ in the absence or the presence of SOM230 and catecholamine secretion was monitored using carbon fiber amperometry. (a) Example of a typical amperometric recording obtained from untreated cells (controls, top) or a cell treated with $1 \mu \mathrm{M}$ SOM230 in pipette (patient 3, bottom left), or with $0.1 \mu \mathrm{M}$ SOM230 in the cell incubation bath (patient 7, bottom right). (b) Representation of the mean number of spikes per cell in response to SOM230. Patients (P) are color-coded. SOM230 was present in the stimulation pipette (left) or added directly to the incubation bath (right) and the concentration is indicated. (c) Superimposition of average spike obtained for cells of each patient according to treatment conditions. SOM230 was applied either through the stimulation pipette (top) or in the incubation bath (bottom). All the average amperometric data are detailed in Table 3.

\subsection{Effect of SOM230 on intracellular calcium levels and membrane currents evoked by nicotine in human pheochromocytoma cells}

Nicotine-induced stimulation of exocytosis in chromaffin cells triggers an elevation of intracellular calcium concentration $\left(\left[\mathrm{Ca}^{2+}\right]_{\mathrm{i}}\right)[43]$. We therefore examined whether the rise in $\left[\mathrm{Ca}^{2+}\right]_{\mathrm{i}}$-induced by nicotine was inhibited by SOM230. To this end, we performed $\left[\mathrm{Ca}^{2+}\right]_{\mathrm{i}}$ imaging at single-cell resolution in tumor cells from 3 different human Pheos (patients 5, 6 and 10; Figure 4). Stimulation of chromaffin cells with $15 \mu \mathrm{M}$ nicotine generated a rapid increase in $\left[\mathrm{Ca}^{2+}\right]_{\mathrm{i}}$ (Figure $\left.4 \mathrm{~A}\right)$. Co-application of nicotine with 1 or $10 \mu \mathrm{M}$ SOM230 reduced the amplitude of $\left[\mathrm{Ca}^{2+}\right]_{\mathrm{i}}$ by $29 \%$ and $42 \%$ respectively and the total integrated signal (area under the curve) by $45 \%$ and $58 \%$ respectively (Figure $4 \mathrm{~B}$ ).

Since SOM230 reduced $\left[\mathrm{Ca}^{2+}\right]_{\text {i }}$ responses to nicotine, we examined whether it affected the membrane currents evoked by nicotine. To this end, we performed whole-cell patch-clamp recordings in the voltage-clamp mode on human tumor cells cultured from 3 different Pheos (patients 7, 8 and 9). Co-application of $15 \mu \mathrm{M}$ nicotine with $\operatorname{SOM} 230(1,5$ or $10 \mu \mathrm{M})$ significantly reduced the amplitude and the area under the curve of the current evoked by nicotine in a concentration-dependent manner (Figure 5). On average, 1, 5 and $10 \mu \mathrm{M}$ SOM230 respectively reduced the amplitude of nicotine-induced current by 5\%,14\% and $25 \%$ and the area under the curve by $20 \%, 43 \%$ and $62 \%$. These data indicate that SOM230 has a fast and concentration-dependent action on the function of nicotinic receptors. 
A

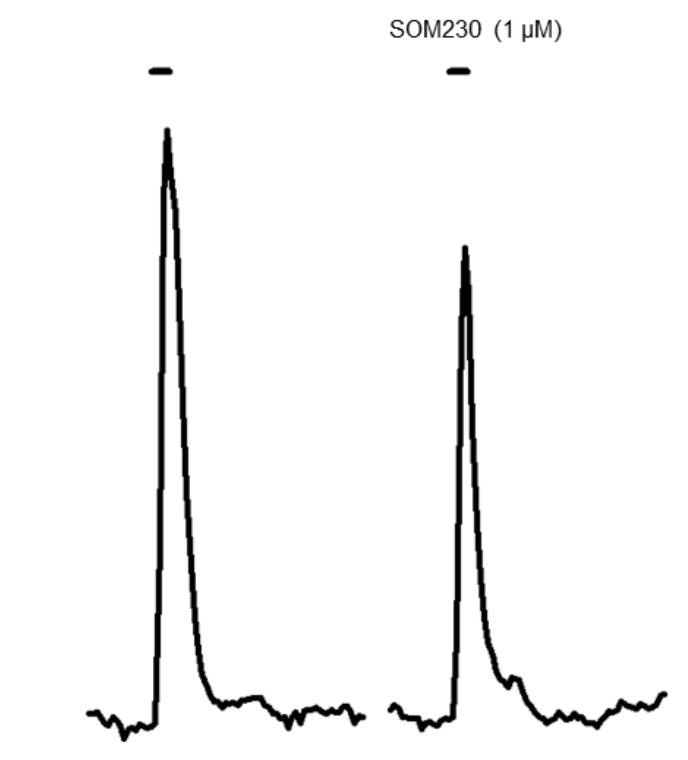

$\operatorname{SOM} 230(10 \mu \mathrm{M})$

B
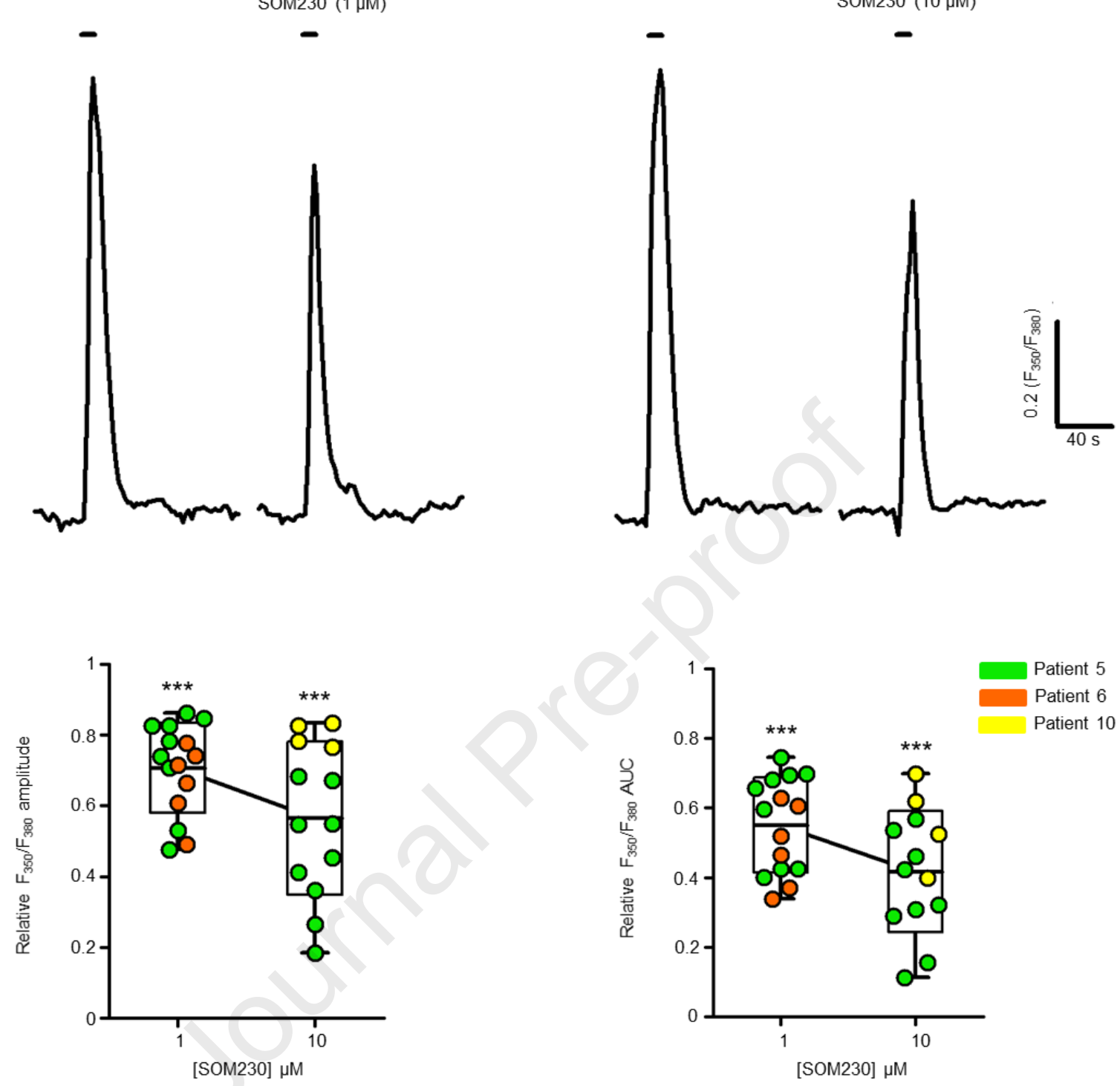

$B$

Figure 4. Dose-dependent inhibition by SOM230 of calcium transients evoked by brief nicotine application on tumor cells from human pheochromocytoma.

(a) Example of typical traces of calcium transients, represented as ratiometric changes in fluorescence emission during $10 \mathrm{~s}$ applications of nicotine $15 \mu \mathrm{M}$ or during co-applications of nicotine with SOM230 1 or $10 \mu \mathrm{M}$ on human pheochromocytoma (data from Patient 5). Nicotine application times are indicated by the horizontal lines. (b) Average amplitude (left) and area under the curve (AUC, right) of the ratiometric changes induced by $15 \mu \mathrm{M}$ nicotine co-applied with SOM230 1 and $10 \mu \mathrm{M}$ normalized to the ratiometric changes induced by $15 \mu \mathrm{M}$ nicotine alone. ${ }^{* * *} \mathrm{p}<0.001$ compared to control; Wilcoxon Rank Sum test. 
A

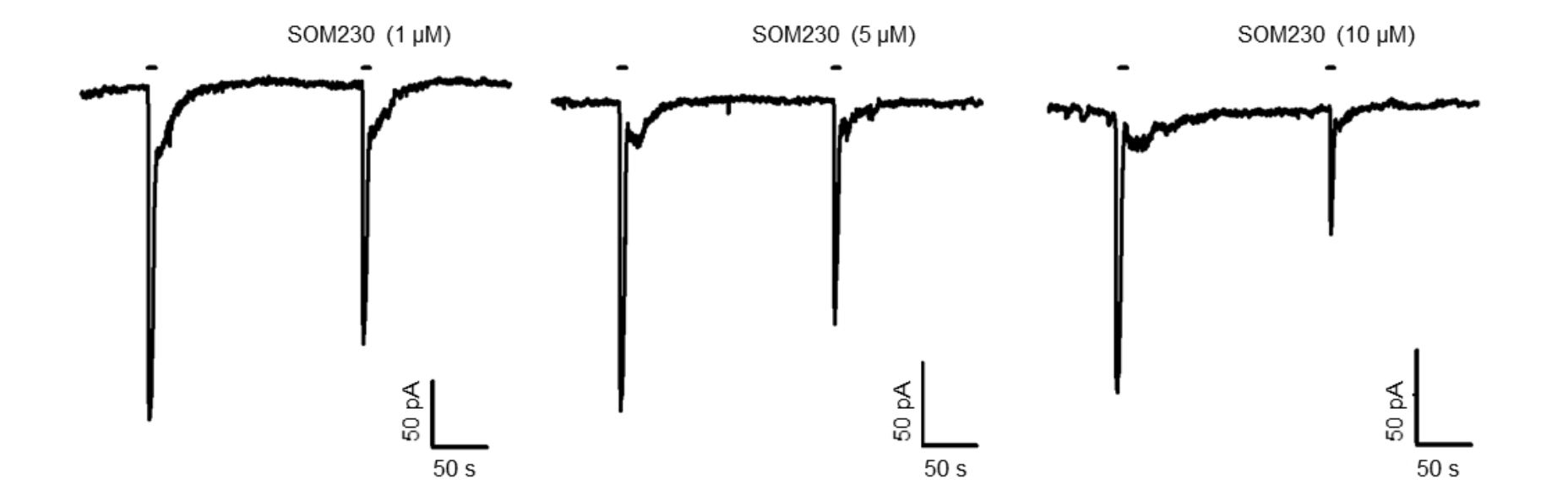

B
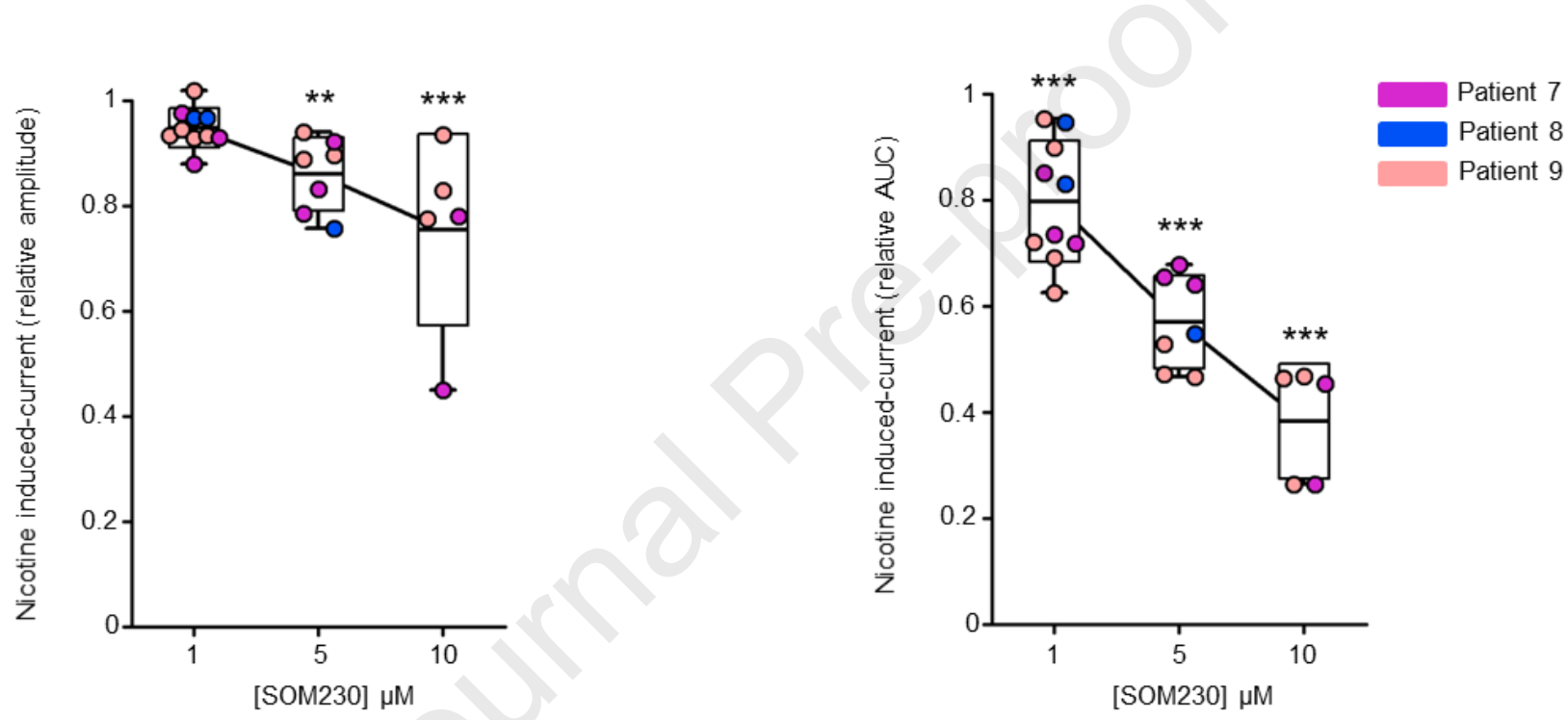

Figure 5. Dose-dependent inhibition by SOM230 of currents evoked by brief nicotine application on tumor cells from human pheochromocytoma.

(a) Example of currents induced by $3 \mathrm{~s}$ applications of nicotine $15 \mu \mathrm{M}$ recorded in a cell incubated with 1,5 or $10 \mu \mathrm{M}$ SOM 230 (data from Patient 7). When SOM230 is co-applied with nicotine, the amplitude of the current is reduced. Nicotine application times are indicated by the horizontal lines. (b) Average amplitude (left) and area under the curve (AUC, right) of the current induced by nicotine coapplied with SOM230 1, 5 and $10 \mu \mathrm{M}$ normalized to the current induced by $15 \mu \mathrm{M}$ nicotine alone. ${ }^{* * \mathrm{p}}<0.01$; *** $<$ 0.001 compared to control; Wilcoxon Rank Sum test. 


\section{DISCUSSION}

Historically misunderstood as relatively rare and harmless, current understanding shows that NETs are increasingly common and are now regarded as neoplasms that can cause debilitating symptoms and are life-threatening for patients. Indeed, loss of control of hormone secretion by NETs can result in a broad spectrum of symptoms and clinical syndromes ranging from feeling ill up to severe complications such as hypertension, hypoglycemia, carcinoid syndrome, cardiopathy and stroke. Moreover, NETs with initial low secretory activity can transform into high secreting lesions with negative impact on prognosis just by progressively becoming hormonally active [44-47]. Today, an unmet need is to identify drugs targeting the secretory activity of the tumor.

The main anti-secretory therapies currently used in clinic on patients with certain NETs and endocrine syndromes are the somatostatin analogues [48, 49]. However, the impact of somatostatin analogues on pheochromocytoma-associated catecholamine hypersecretion has been poorly explored in vitro. First, we tested the effect of octreotide and pasireotide (SOM230), two different-generation somatostatin analogues, on animal model (bovine chromaffin cells) by measuring catecholamine release either at the whole population level by the adrenolutine assay and mass spectrometry or at the single cell level by carbon fiber amperometry. Using these 3 methods, we have shown that the somatostatin analogue SOM230 efficiently inhibits the nicotine-evoked catecholamine secretion, whereas octreotide has no significant effect. In agreement with our observations, Ribeiro et al. reported that octreotide had no effect on 1-methyl-4-phenylpyridinium secretion from ent the bovine chromaffin cells [50]. Moreover, the potential use of octreotide for Pheo treatment has been already investigated in clinic. Except for very few cases [51, 52], octreotide treatment did not significantly affect catecholamine secretion. For example, octreotide treatment did not significantly change the level of plasma and urinary catecholamine or metanephrine compared to placebo treatment in several patients with benign or malignant Pheo $[53,54]$. Likewise, urinary catecholamine levels remained unchanged after octreotide treatment of patients with secreting head and neck paraganglioma [55].

As we observed an important inhibition of bovine chromaffin cell secretion by SOM230, we next tested this analogue on human tumor cells directly cultured from freshly resected Pheo. We show here that SOM230 inhibits catecholamine secretion of tumor cells with a significant 
effect starting from $0.1 \mu \mathrm{M}$. To our knowledge, this is the first evidence of an inhibitory effect of SOM230 on catecholamine secretion from human Pheo cells. Nevertheless, in agreement with our observations, the effect of SOM230 on hormone secretion has been tested on various types of other tumor cells in vitro. For example, SOM230 efficiently inhibits prolactine, growth hormone and adrenocorticotropic hormone secretion from primary cultures of human secreting pituitary adenomas $[56,57]$. It also significantly decreases secretion of chromogranin A in cells cultured from tumor of human gastroenteropancreatic NETs [20]. Moreover, Quinn et al. demonstrated in vivo, in a mouse model with insulinoma, that SOM230 injection inhibits hypersecretion of insulin thus preventing hypoglycemia [58].

Using carbon fiber amperometry, we have further dissected the anti-secretory effect of SOM230 on the exocytic pathway. The main effect observed after the application of $0.1 \mu \mathrm{M}$ SOM230 was an important inhibition of the number of exocytic events on both bovine chromaffin cells (decreased by around 60\%) and human tumor cells (decrease ranging from 42 to $88 \%$; patients 5 to 8). Note that, due to the dilution factor, the effect seen with $0.1 \mu \mathrm{M}$ in bath of SOM230 corresponds more or less to the one seen with $1 \mu \mathrm{M}$ co-incubated with nicotine in the stimulation pipette. Accordingly, under the latter experimental condition, the number of exocytic events was reduced by SOM230 with a comparable efficiency (by 43 and $61 \%$ in patients 3 and 4, respectively and by $75 \%$ in average for bovine model). These results support the notion that SOM230 affects early steps in the exocytotic process, such as the recruitment of the secretory granules or their docking at the plasma membrane. Moreover, the analysis of the amperometric parameters revealed that the amplitude of the remaining exocytic events tends to be lower upon SOM230 treatment, an effect sometimes accompanied by a decrease of the kinetics. This suggests that, even when secretory granule fusion is engaged, the release might be disturbed, being incomplete and/or slowed down. To our knowledge, only a single study investigated the in vitro effect of SOM230 on tumor cells cultured from human Pheos. Hence, Pasquali et al. showed that a long-lasting $(24 \mathrm{~h})$ treatment of 0.1 and $1 \mu \mathrm{M}$ SOM230 significantly decreased the intracellular content of dopamine and noradrenaline [28]. However, in contrast to our study, they didn't measure the secretory activity of the tumor cells. A reduction of cellular catecholamine levels can be the consequence of a decrease in the number of secretory granules and/or the level of catecholamine per granules. In our study, the total amount of catecholamines in cells remains unchanged which was expected because relatively short SOM230 treatments were performed. This indicates that the effect we observed on secretion is necessarily independent from its potential long-term effect on catecholamine metabolism. It is also of note that the inhibitory effect of SOM230 on catecholamine release 
was seen only when the drug was present during the stimulation period and a pre-incubation period did not significantly further increase this inhibition of secretion (data not shown). These data show that the effect of SOM230 is rapid and that a long pre-incubation is not required.

In our experimental conditions, we found that SOM230 drastically inhibited catecholamine secretion of tumor cells at $100 \mathrm{nM}$ but not at $10 \mathrm{nM}$. Accordingly, inhibitory effects with similar concentration have been previously observed in cells cultured from human cancer such as growth hormone-secreting pituitary adenoma and growth hormone-releasing hormoneproducing bronchial carcinoid $[59,60]$. However, this concentration is relatively high compared to the $\mathrm{IC}_{50}$ (ranging from 0.2 to $1 \mathrm{nM}$ ) reported after long lasting treatment of SOM230 on the secretory activity of rat pituitary cells, rat pancreatic islets, mouse corticotroph adenoma cells and human pituitary adenoma cells $[56,57,61,62]$, raising the question of the mechanisms by which SOM230 inhibits catecholamine secretion in human Pheo cells. As frequency and amplitude of exocytic events depend on the level of secretagogue-evoked intracellular calcium elevation $[63,64]$, it was tempting to imagine that SOM230 might affect secretory granule exocytosis upstream of calcium entry. Indeed, we showed that SOM230 significantly inhibited nicotine-evoked increase of intracellular calcium in human tumor cells. One other interesting aspect is that SOM230 acts instantly and exclusively on secretion induced by nicotine without affecting secretion induced by high $\mathrm{K}^{+}$solution. In agreement with our results, several studies demonstrated that somatostatin itself was able to inhibit catecholamine release when chromaffin cells are stimulated with nicotine or acetylcholine but not upon membrane depolarization [39, $40,65,66]$. In fact, we show here by whole cell recordings in the voltage-clamp mode that SOM230 is able to reduce the nicotinic current. Since membrane potential remains constant under these recording conditions, this effect most likely involves an effect on the function of nicotinic receptors and not on voltage-dependent $\mathrm{Na}^{+}$and $\mathrm{Ca}^{2+}$ channels. Accordingly, coapplication of somatostatin with nicotine reversibly inhibits the nicotine-induced inward current in guinea pig chromaffin cells [67]. Whether SOM230 indirectly affects the function of the nicotinic receptor via its own somatostatin receptor or via a direct action on the nicotinic receptor is currently unknown. Interestingly, several evidences indicated that somatostatin receptors are able to either homo-oligomerize or to hetero-oligomerize between different subtypes of somatostatin receptors or with other types of receptor like the dopamine receptor D2 or the $\mu$-opioid receptor MOR1 [68-72]. Potential oligomerization between somatostatin and nicotinic receptors has never been reported and will require further investigations. 
This pre-clinical study allowed us to uncover a novel anti-secretory role of SOM230 on tumor adrenal medulla cells from patients with functional Pheo and abnormal secretion. If SOM230 treatment could actually improve the management of patients remains a key question that will require further clinical studies. As SOM230 efficiently inhibits catecholamine secretion by directly acting on the tumor secretion, it might be considered for preoperative medical preparation or intraoperative management of highly secreting Pheo. SOM230 might also be useful to treat some metastatic Pheos resistant to conventional antihypertensive medications, especially as high hormonal secretion impacts overall survival in patient with metastatic Pheo [73]. Moreover, as long lasting effect of SOM230 is known to reduce catecholamine synthesis in Pheo cells [28], treatment of patients may lead to a combination of reduced catecholamine synthesis and secretion which is in fact likely to boost the effect of SOM230 on lowering catecholamine levels in patient with Pheo.

In conclusion, a long-acting release formulation of SOM230 might be a potential lead to consider a therapy aimed at treating the symptoms induced by excessive catecholamine secretion of Pheo. This new data may be used to better control catecholamine hypersecretion when needed and should be evaluated in clinical practice. 


\section{Ethics approval and consent to participate}

The present study used the data and the human biological material of the biological collection “Approche moléculaire des tumeurs corticosurrénaliennes" which was agreed by the "Comité de Protection des Personnes Est III" ethical advisory committee, and was conducted according to currently accepted ethical guidelines, including informed written consent approval signed by all patients prior to inclusion.

\section{Fundings and acknowledgements}

This work was financially supported by ITMO Cancer AVIESAN (Alliance Nationale pour les Sciences de la Vie et de la Santé, National Alliance for Life Sciences \& Health) within the framework of the Cancer Plan to SG and LB (Single Cell $2018 \mathrm{~N}^{\circ}$ 19CS004-00); by grants from the Agence Nationale pour la Recherche ("SecretoNET", N ANR-16-CE17-0022-01) and from the Ligue contre le Cancer (CCIR Grand-Est) to SG; by the University of Strasbourg Institute for Advanced Study (USIAS) for a Fellowship to SG, within the French national programme "Investment for the future" (IdEx-Unistra); by a fellowship from la Fondation pour la Recherche Médicale (FRM; FDM201806005916) to SM. INSERM is providing salary to YG, NV and SG.

We acknowledge the municipal slaughterhouse of Haguenau (France) for providing the bovine adrenal glands. The authors are also grateful to Dr. Nan Qin (University of Dresden, Germany) for her advices on primary culture of human pheochromocytoma cells and to Tamou Thahouly and Alexander Wolf (INCI, CNRS, Strasbourg, France) for their technical assistance on bovine chromaffin cell culture.

\section{Conflict of interest}

The authors declare that there is no conflict of interest that could be perceived as prejudicing the impartiality of the research reported. 


\section{References}

[1] L. Streit, L. Brunaud, N. Vitale, S. Ory, S. Gasman, Hormones Secretion and Rho GTPases in Neuroendocrine Tumors, Cancers (Basel), 12 (2020).

[2] D. Clement, J. Ramage, R. Srirajaskanthan, Update on Pathophysiology, Treatment, and Complications of Carcinoid Syndrome, J Oncol, 2020 (2020) 8341426.

[3] W.T. Zandee, K. Kamp, R.C. van Adrichem, R.A. Feelders, W.W. de Herder, Effect of hormone secretory syndromes on neuroendocrine tumor prognosis, Endocr Relat Cancer, 24 (2017) R261-R274.

[4] B. Oronsky, P.C. Ma, D. Morgensztern, C.A. Carter, Nothing But NET: A Review of Neuroendocrine Tumors and Carcinomas, Neoplasia, 19 (2017) 991-1002.

[5] A. Dasari, C. Shen, D. Halperin, B. Zhao, S. Zhou, Y. Xu, T. Shih, J.C. Yao, Trends in the Incidence, Prevalence, and Survival Outcomes in Patients With Neuroendocrine Tumors in the United States, JAMA Oncol, 3 (2017) 1335-1342.

[6] D.M. Halperin, C. Shen, A. Dasari, Y. Xu, Y. Chu, S. Zhou, Y.T. Shih, J.C. Yao, Frequency of carcinoid syndrome at neuroendocrine tumour diagnosis: a population-based study, Lancet Oncol, 18 (2017) 525-534.

[7] J.W.M. Lenders, M.N. Kerstens, L. Amar, A. Prejbisz, M. Robledo, D. Taieb, K. Pacak, J. Crona, T. Zelinka, M. Mannelli, T. Deutschbein, H. Timmers, F. Castinetti, H. Dralle, J. Widimsky, A.P. Gimenez-Roqueplo, G. Eisenhofer, Genetics, diagnosis, management and future directions of research of phaeochromocytoma and paraganglioma: a position statement and consensus of the Working Group on Endocrine Hypertension of the European Society of Hypertension, J Hypertens, 38 (2020) 1443-1456.

[8] J.M. Pappachan, N.N. Tun, G. Arunagirinathan, R. Sodi, F.W.F. Hanna, Pheochromocytomas and Hypertension, Curr Hypertens Rep, 20 (2018) 3.

[9] M. Pourian, D.B. Mostafazadeh, A. Soltani, Does this patient have pheochromocytoma? A systematic review of clinical signs and symptoms, J Diabetes Metab Disord, 15 (2015) 11. [10] S. Y-Hassan, H. Falhammar, Cardiovascular Manifestations and Complications of Pheochromocytomas and Paragangliomas, J Clin Med, 9 (2020).

[11] R. Zhang, D. Gupta, S.G. Albert, Pheochromocytoma as a reversible cause of cardiomyopathy: Analysis and review of the literature, Int J Cardiol, 249 (2017) 319-323.

[12] R.F. Stolk, C. Bakx, J. Mulder, H.J. Timmers, J.W. Lenders, Is the excess cardiovascular morbidity in pheochromocytoma related to blood pressure or to catecholamines?, J Clin Endocrinol Metab, 98 (2013) 1100-1106.

[13] A.R. McNeil, B.H. Blok, T.D. Koelmeyer, M.P. Burke, J.M. Hilton, Phaeochromocytomas discovered during coronial autopsies in Sydney, Melbourne and Auckland, Aust N Z J Med, 30 (2000) 648-652.

[14] J.K. Platts, P.J. Drew, J.N. Harvey, Death from phaeochromocytoma: lessons from a post-mortem survey, J R Coll Physicians Lond, 29 (1995) 299-306.

[15] A. Jain, R. Baracco, G. Kapur, Pheochromocytoma and paraganglioma-an update on diagnosis, evaluation, and management, Pediatr Nephrol, 35 (2020) 581-594.

[16] G. Lebuffe, E.D. Dosseh, G. Tek, H. Tytgat, S. Moreno, B. Tavernier, B. Vallet, C.A. Proye, The effect of calcium channel blockers on outcome following the surgical treatment of phaeochromocytomas and paragangliomas, Anaesthesia, 60 (2005) 439-444.

[17] L. Brunaud, M. Boutami, P.L. Nguyen-Thi, B. Finnerty, A. Germain, G. Weryha, T.J. Fahey, 3rd, E. Mirallie, L. Bresler, R. Zarnegar, Both preoperative alpha and calcium channel blockade impact intraoperative hemodynamic stability similarly in the management of pheochromocytoma, Surgery, 156 (2014) 1410-1417; discussion1417-1418. 
[18] G. Mazziotti, A. Mosca, S. Frara, G. Vitale, A. Giustina, Somatostatin analogs in the treatment of neuroendocrine tumors: current and emerging aspects, Expert Opin

Pharmacother, 18 (2017) 1679-1689.

[19] K. Oberg, S.W. Lamberts, Somatostatin analogues in acromegaly and gastroenteropancreatic neuroendocrine tumours: past, present and future, Endocr Relat Cancer, 23 (2016) R551-R566.

[20] A. Mohamed, M.P. Blanchard, M. Albertelli, F. Barbieri, T. Brue, P. Niccoli, J.R. Delpero, G. Monges, S. Garcia, D. Ferone, T. Florio, A. Enjalbert, V. Moutardier, A.

Schonbrunn, C. Gerard, A. Barlier, A. Saveanu, Pasireotide and octreotide antiproliferative effects and sst 2 trafficking in human pancreatic neuroendocrine tumor cultures, Endocr Relat Cancer, 21 (2014) 691-704.

[21] M. Michael, R. Garcia-Carbonero, M.M. Weber, C. Lombard-Bohas, C. Toumpanakis, R.J. Hicks, The Antiproliferative Role of Lanreotide in Controlling Growth of

Neuroendocrine Tumors: A Systematic Review, Oncologist, 22 (2017) 272-285.

[22] H.A. Schmid, Pasireotide (SOM230): development, mechanism of action and potential applications, Mol Cell Endocrinol, 286 (2008) 69-74.

[23] C. Susini, L. Buscail, Rationale for the use of somatostatin analogs as antitumor agents, Ann Oncol, 17 (2006) 1733-1742.

[24] D. Cuevas-Ramos, M. Fleseriu, Pasireotide: a novel treatment for patients with acromegaly, Drug Des Devel Ther, 10 (2016) 227-239.

[25] R. Pivonello, R. Ferrigno, M.C. De Martino, C. Simeoli, N. Di Paola, C. Pivonello, L. Barba, M. Negri, C. De Angelis, A. Colao, Medical Treatment of Cushing's Disease: An Overview of the Current and Recent Clinical Trials, Front Endocrinol (Lausanne), 11 (2020) 648.

[26] L.K. Kvols, K.E. Oberg, T.M. O'Dorisio, P. Mohideen, W.W. de Herder, R. Arnold, K. Hu, Y. Zhang, G. Hughes, L. Anthony, B. Wiedenmann, Pasireotide (SOM230) shows efficacy and tolerability in the treatment of patients with advanced neuroendocrine tumors refractory or resistant to octreotide LAR: results from a phase II study, Endocr Relat Cancer, 19 (2012) 657-666.

[27] H. Leijon, S. Remes, J. Hagstrom, J. Louhimo, H. Maenpaa, C. Schalin-Jantti, M. Miettinen, C. Haglund, J. Arola, Variable somatostatin receptor subtype expression in 151 primary pheochromocytomas and paragangliomas, Hum Pathol, 86 (2019) 66-75.

[28] D. Pasquali, V. Rossi, G. Conzo, G. Pannone, P. Bufo, A. De Bellis, A. Renzullo, G. Bellastella, A. Colao, G. Vallone, A. Bellastella, A.A. Sinisi, Effects of somatostatin analog SOM230 on cell proliferation, apoptosis, and catecholamine levels in cultured pheochromocytoma cells, J Mol Endocrinol, 40 (2008) 263-271.

[29] J.W. Lenders, Q.Y. Duh, G. Eisenhofer, A.P. Gimenez-Roqueplo, S.K. Grebe, M.H. Murad, M. Naruse, K. Pacak, W.F. Young, Jr., S. Endocrine, Pheochromocytoma and paraganglioma: an endocrine society clinical practice guideline, J Clin Endocrinol Metab, 99 (2014) 1915-1942.

[30] N.G.S.i.P.S. Group, R.A. Toledo, N. Burnichon, A. Cascon, D.E. Benn, J.P. Bayley, J. Welander, C.M. Tops, H. Firth, T. Dwight, T. Ercolino, M. Mannelli, G. Opocher, R. CliftonBligh, O. Gimm, E.R. Maher, M. Robledo, A.P. Gimenez-Roqueplo, P.L. Dahia, Consensus Statement on next-generation-sequencing-based diagnostic testing of hereditary phaeochromocytomas and paragangliomas, Nat Rev Endocrinol, 13 (2017) 233-247. [31] G. Eisenhofer, J.W. Lenders, D.S. Goldstein, M. Mannelli, G. Csako, M.M. Walther, F.M. Brouwers, K. Pacak, Pheochromocytoma catecholamine phenotypes and prediction of tumor size and location by use of plasma free metanephrines, Clin Chem, 51 (2005) 735-744. 
[32] L.D. Thompson, Pheochromocytoma of the Adrenal gland Scaled Score (PASS) to separate benign from malignant neoplasms: a clinicopathologic and immunophenotypic study of 100 cases, Am J Surg Pathol, 26 (2002) 551-566.

[33] T. Thahouly, E. Tanguy, J. Raherindratsara, M.F. Bader, S. Chasserot-Golaz, S. Gasman, N. Vitale, Bovine Chromaffin Cells: Culture and Fluorescence Assay for Secretion, Methods Mol Biol, 2233 (2021) 169-179.

[34] S. Moog, S. Houy, E. Chevalier, S. Ory, G. Weryha, M. Rame, M. Klein, L. Brunaud, S. Gasman, T. Cuny, 18F-FDOPA PET/CT Uptake Parameters Correlate with Catecholamine Secretion in Human Pheochromocytomas, Neuroendocrinology, 107 (2018) 228-236.

[35] R.H. Liu, G. Foster, E.J. Cone, S.D. Kumar, Selecting an appropriate isotopic internal standard for gas chromatography/mass spectrometry analysis of drugs of abuse--pentobarbital example, J Forensic Sci, 40 (1995) 983-989.

[36] E. Tanguy, P. Coste de Bagneaux, N. Kassas, M.R. Ammar, Q. Wang, A.M. Haeberle, J. Raherindratsara, L. Fouillen, P.Y. Renard, M. Montero-Hadjadje, S. Chasserot-Golaz, S. Ory, S. Gasman, M.F. Bader, N. Vitale, Mono- and Poly-unsaturated Phosphatidic Acid Regulate Distinct Steps of Regulated Exocytosis in Neuroendocrine Cells, Cell Rep, 32 (2020) 108026. [37] S. Houy, C. Estay-Ahumada, P. Croise, V. Calco, A.M. Haeberle, Y. Bailly, P. Billuart, N. Vitale, M.F. Bader, S. Ory, S. Gasman, Oligophrenin-1 Connects Exocytotic Fusion to Compensatory Endocytosis in Neuroendocrine Cells, J Neurosci, 35 (2015) 11045-11055. [38] F. Segura, M.A. Brioso, J.F. Gomez, J.D. Machado, R. Borges, Automatic analysis for amperometrical recordings of exocytosis, J Neurosci Methods, 103 (2000) 151-156.

[39] F. Mizobe, V. Kozousek, D.M. Dean, B.G. Livett, Pharmacological characterization of adrenal paraneurons: substance $\mathrm{P}$ and somatostatin as inhibitory modulators of the nicotinic response, Brain Res, 178 (1979) 555-566.

[40] I. Moeller, S.J. Bunn, P.D. Marley, Actions of somatostatin on perfused bovine adrenal glands and cultured bovine adrenal medullary cells, Brain Res, 484 (1989) 192-202.

[41] E.V. Mosharov, D. Sulzer, Analysis of exocytotic events recorded by amperometry, Nat Methods, 2 (2005) 651-658.

[42] D.J. Keating, Amperometry in Single Cells and Tissue, Methods Mol Biol, 2233 (2021) 223-231.

[43] S.H. Gerber, A. Haunstetter, C. Kruger, A. Kaufmann, R. Nobiling, M. Haass, Role of $[\mathrm{Na}+] \mathrm{i}$ and $[\mathrm{Ca} 2+] \mathrm{i}$ in nicotine-induced norepinephrine release from bovine adrenal chromaffin cells, Am J Physiol, 269 (1995) C572-581.

[44] C.C. Juhlin, S. Skoglund, L. Juntti-Berggren, M. Karlberg, J. Calissendorff, Nonfunctioning neuroendocrine pancreatic tumors transforming to malignant insulinomas - four cases and review of the literature, Neuro Endocrinol Lett, 40 (2019) 175-183.

[45] P. Song, H.S. Sekhon, Y. Jia, J.A. Keller, J.K. Blusztajn, G.P. Mark, E.R. Spindel, Acetylcholine is synthesized by and acts as an autocrine growth factor for small cell lung carcinoma, Cancer Res, 63 (2003) 214-221.

[46] R.L. Brown, T. Muzzafar, R. Wollman, R.E. Weiss, A pituitary carcinoma secreting TSH and prolactin: a non-secreting adenoma gone awry, Eur J Endocrinol, 154 (2006) 639-643.

[47] T. Daems, J. Verhelst, A. Michotte, P. Abrams, D. De Ridder, R. Abs, Modification of hormonal secretion in clinically silent pituitary adenomas, Pituitary, 12 (2009) 80-86.

[48] U. Rai, T.R. Thrimawithana, C. Valery, S.A. Young, Therapeutic uses of somatostatin and its analogues: Current view and potential applications, Pharmacol Ther, 152 (2015) 98110.

[49] A.K. Stueven, A. Kayser, C. Wetz, H. Amthauer, A. Wree, F. Tacke, B. Wiedenmann, C. Roderburg, H. Jann, Somatostatin Analogues in the Treatment of Neuroendocrine Tumors: Past, Present and Future, Int J Mol Sci, 20 (2019). 
[50] L. Ribeiro, F. Martel, I. Azevedo, The release of 3H-1-methyl-4-phenylpyridinium from bovine adrenal chromaffin cells is modulated by somatostatin, Regul Pept, 137 (2006) 107113.

[51] C. Invitti, I. De Martin, G.B. Bolla, F. Pecori Giraldi, E. Maestri, G. Leonetti, F. Cavagnini, Effect of octreotide on catecholamine plasma levels in patients with chromaffin cell tumors, Horm Res, 40 (1993) 156-160.

[52] N. Koriyama, M. Kakei, K. Yaekura, H. Okui, T. Yamashita, H. Nishimura, S. Matsushita, C. Tei, Control of catecholamine release and blood pressure with octreotide in a patient with pheochromocytoma: a case report with in vitro studies, Horm Res, 53 (2000) 4650.

[53] P.F. Plouin, J. Bertherat, G. Chatellier, E. Billaud, M. Azizi, E. Grouzmann, J. Epelbaum, Short-term effects of octreotide on blood pressure and plasma catecholamines and neuropeptide Y levels in patients with phaeochromocytoma: a placebo-controlled trial, Clin Endocrinol (Oxf), 42 (1995) 289-294.

[54] M. Lamarre-Cliche, A.P. Gimenez-Roqueplo, E. Billaud, E. Baudin, J.P. Luton, P.F. Plouin, Effects of slow-release octreotide on urinary metanephrine excretion and plasma chromogranin A and catecholamine levels in patients with malignant or recurrent phaeochromocytoma, Clin Endocrinol (Oxf), 57 (2002) 629-634.

[55] L.T. van Hulsteijn, N. van Duinen, B.M. Verbist, J.C. Jansen, A.A. van der Klaauw, J.W. Smit, E.P. Corssmit, Effects of octreotide therapy in progressive head and neck paragangliomas: case series, Head Neck, 35 (2013) E391-396.

[56] L.J. Hofland, J. van der Hoek, R. Feelders, M.O. van Aken, P.M. van Koetsveld, M. Waaijers, D. Sprij-Mooij, C. Bruns, G. Weckbecker, W.W. de Herder, A. Beckers, S.W. Lamberts, The multi-ligand somatostatin analogue SOM230 inhibits ACTH secretion by cultured human corticotroph adenomas via somatostatin receptor type 5, Eur J Endocrinol, 152 (2005) 645-654.

[57] L.J. Hofland, J. van der Hoek, P.M. van Koetsveld, W.W. de Herder, M. Waaijers, D. Sprij-Mooij, C. Bruns, G. Weckbecker, R. Feelders, A.J. van der Lely, A. Beckers, S.W. Lamberts, The novel somatostatin analog SOM230 is a potent inhibitor of hormone release by growth hormone- and prolactin-secreting pituitary adenomas in vitro, J Clin Endocrinol Metab, 89 (2004) 1577-1585.

[58] T.J. Quinn, Z. Yuan, A. Adem, R. Geha, C. Vrikshajanani, W. Koba, E. Fine, D.T. Hughes, H.A. Schmid, S.K. Libutti, Pasireotide (SOM230) is effective for the treatment of pancreatic neuroendocrine tumors (PNETs) in a multiple endocrine neoplasia type 1 (MEN1) conditional knockout mouse model, Surgery, 152 (2012) 1068-1077.

[59] A. Ibanez-Costa, E. Rivero-Cortes, M.C. Vazquez-Borrego, M.D. Gahete, L. JimenezReina, E. Venegas-Moreno, A. de la Riva, M.A. Arraez, I. Gonzalez-Molero, H.A. Schmid, S. Maraver-Selfa, I. Gavilan-Villarejo, J.A. Garcia-Arnes, M.A. Japon, A. Soto-Moreno, M.A. Galvez, R.M. Luque, J.P. Castano, Octreotide and pasireotide (dis)similarly inhibit pituitary tumor cells in vitro, J Endocrinol, 231 (2016) 135-145.

[60] M. van Hoek, L.J. Hofland, Y.B. de Rijke, F.H. van Nederveen, R.R. de Krijger, P.M. van Koetsveld, S.W. Lamberts, A.J. van der Lely, W.W. de Herder, R.A. Feelders, Effects of somatostatin analogs on a growth hormone-releasing hormone secreting bronchial carcinoid, in vivo and in vitro studies, J Clin Endocrinol Metab, 94 (2009) 428-433.

[61] C. Bruns, I. Lewis, U. Briner, G. Meno-Tetang, G. Weckbecker, SOM230: a novel somatostatin peptidomimetic with broad somatotropin release inhibiting factor (SRIF) receptor binding and a unique antisecretory profile, Eur J Endocrinol, 146 (2002) 707-716. [62] E. Ludvigsen, M. Stridsberg, J.E. Taylor, M.D. Culler, K. Oberg, E.T. Janson, S. Sandler, Regulation of insulin and glucagon secretion from rat pancreatic islets in vitro by somatostatin analogues, Regul Pept, 138 (2007) 1-9. 
[63] M. Bretou, C. Anne, F. Darchen, A fast mode of membrane fusion dependent on tight SNARE zippering, J Neurosci, 28 (2008) 8470-8476.

[64] A. Elhamdani, H.C. Palfrey, C.R. Artalejo, Quantal size is dependent on stimulation frequency and calcium entry in calf chromaffin cells, Neuron, 31 (2001) 819-830.

[65] L.W. Role, S.E. Leeman, R.L. Perlman, Somatostatin and substance P inhibit catecholamine secretion from isolated cells of guinea-pig adrenal medulla, Neuroscience, 6 (1981) 1813-1821.

[66] B.G. Livett, P. Boksa, Receptors and receptor modulation in cultured chromaffin cells, Can J Physiol Pharmacol, 62 (1984) 467-476.

[67] M. Inoue, H. Kuriyama, Somatostatin inhibits the nicotinic receptor-activated inward current in guinea pig chromaffin cells, Biochem Biophys Res Commun, 174 (1991) 750-757. [68] M. Rocheville, D.C. Lange, U. Kumar, S.C. Patel, R.C. Patel, Y.C. Patel, Receptors for dopamine and somatostatin: formation of hetero-oligomers with enhanced functional activity, Science, 288 (2000) 154-157.

[69] M. Grant, H. Alturaihi, P. Jaquet, B. Collier, U. Kumar, Cell growth inhibition and functioning of human somatostatin receptor type 2 are modulated by receptor heterodimerization, Mol Endocrinol, 22 (2008) 2278-2292.

[70] M. Pfeiffer, T. Koch, H. Schroder, M. Klutzny, S. Kirscht, H.J. Kreienkamp, V. Hollt, S. Schulz, Homo- and heterodimerization of somatostatin receptor subtypes. Inactivation of sst(3) receptor function by heterodimerization with sst(2A), J Biol Chem, 276 (2001) 1402714036.

[71] M. Pfeiffer, T. Koch, H. Schroder, M. Laugsch, V. Hollt, S. Schulz, Heterodimerization of somatostatin and opioid receptors cross-modulates phosphorylation, internalization, and desensitization, J Biol Chem, 277 (2002) 19762-19772.

[72] R.K. Somvanshi, S.A. War, N. Chaudhari, X. Qiu, U. Kumar, Receptor specific crosstalk and modulation of signaling upon heterodimerization between beta1-adrenergic receptor and somatostatin receptor-5, Cell Signal, 23 (2011) 794-811.

[73] S. Hescot, M. Curras-Freixes, T. Deutschbein, A. van Berkel, D. Vezzosi, L. Amar, C. de la Fouchardiere, N. Valdes, F. Riccardi, C. Do Cao, J. Bertherat, B. Goichot, F. Beuschlein, D. Drui, L. Canu, P. Niccoli, S. Laboureau, A. Tabarin, S. Leboulleux, B. Calsina, R. Libe, A. Faggiano, M. Schlumberger, F. Borson-Chazot, M. Mannelli, A.P. Gimenez-Roqueplo, P. Caron, H. Timmers, M. Fassnacht, M. Robledo, I. Borget, E. Baudin, T. European Network for the Study of Adrenal, Prognosis of Malignant Pheochromocytoma and Paraganglioma (MAPP-Prono Study): A European Network for the Study of Adrenal Tumors Retrospective Study, J Clin Endocrinol Metab, 104 (2019) 2367-2374. 

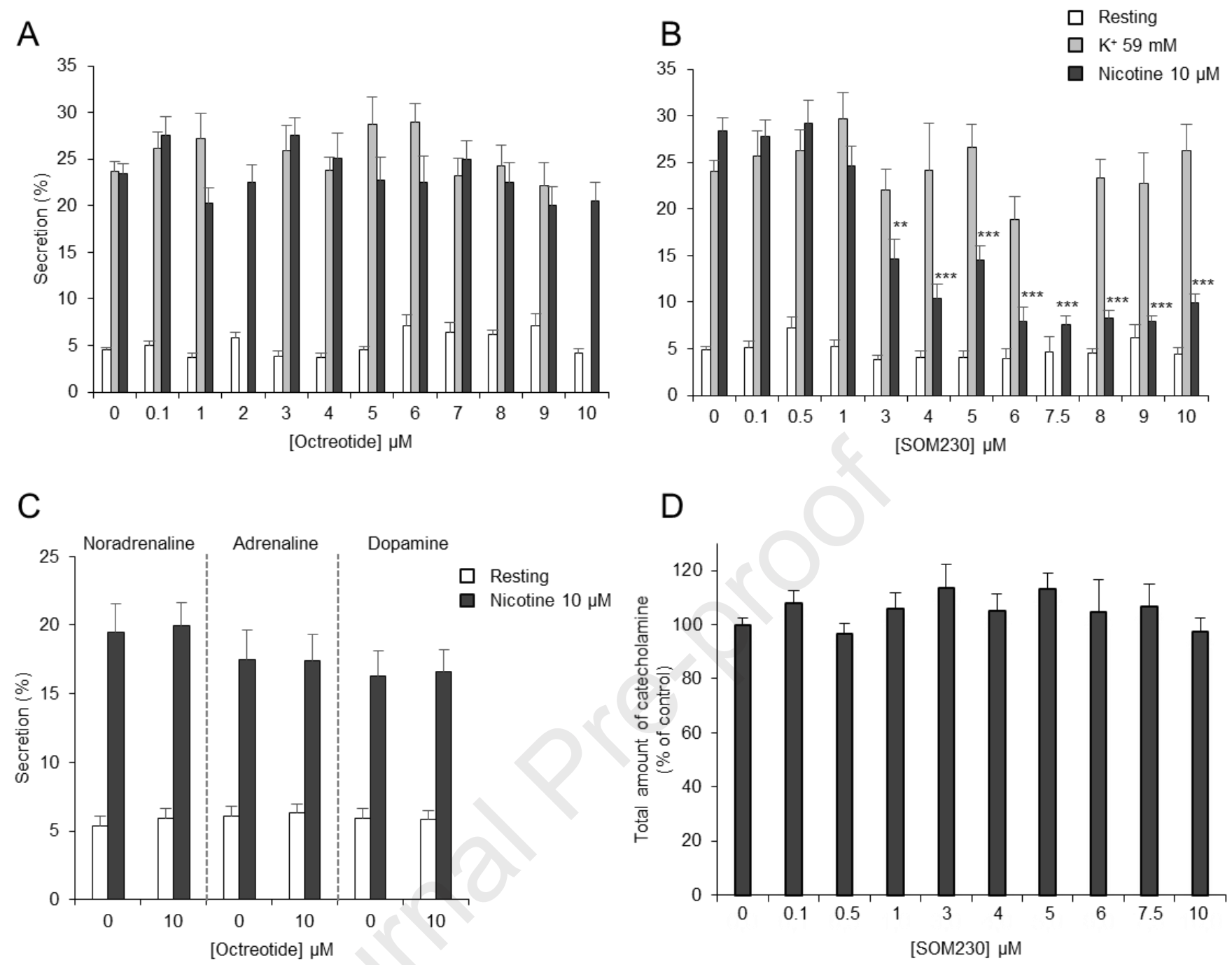

\section{Supplementary Figure 1. Experimental details on the effect of octreotide and SOM230 on catecholamine secretion in bovine chromaffin cells.}

Bovine chromaffin cells were stimulated with $10 \mu \mathrm{M}$ nicotine or with a high $\mathrm{K}^{+}$depolarizing solution $(59 \mathrm{mM})$ for $10 \mathrm{~min}$ in the presence of the indicated concentrations of octreotide or SOM230. Catecholamine amount was estimated using an adrenolutine fluorescent assay (a, b, d) or mass spectrometry (c). ( $a, b)$ Data describing the proportion of catecholamine secreted in resting and stimulated conditions upon treatment of octreotide and SOM230; **p< $0.01, * * * p<0.001$ compared to control; Kruskal-Wallis One Way Analysis of Variance on Ranks followed by Dunn's test or One Way ANOVA. Note that the effect of 2 and $10 \mu \mathrm{M}$ octreotide and $7.5 \mu \mathrm{M}$ SOM230 was not tested upon $\mathrm{K}^{+-}$ stimulation. (c) Effect of $10 \mu \mathrm{M}$ octreotide on noradrenaline, adrenaline and dopamine release measured by mass spectrometry. (d) The total amount of catecholamine in bovine chromaffin cells was calculated from the adrenolutine secretion assay by adding secreted and cellular catecholamines. Cells were stimulated with $10 \mu \mathrm{M}$ nicotine for $10 \mathrm{~min}$ in the presence of the indicated concentrations of SOM230. Catecholamines were then measured both in the extracellular medium and in the cellular extract after stimulation. For each concentration of SOM230, the amounts of total catecholamine were normalized to control (untreated cells) which was fixed to $100 \%$. Data are given as the mean values \pm SEM obtained from different cell cultures $(n \geq 3)$. 


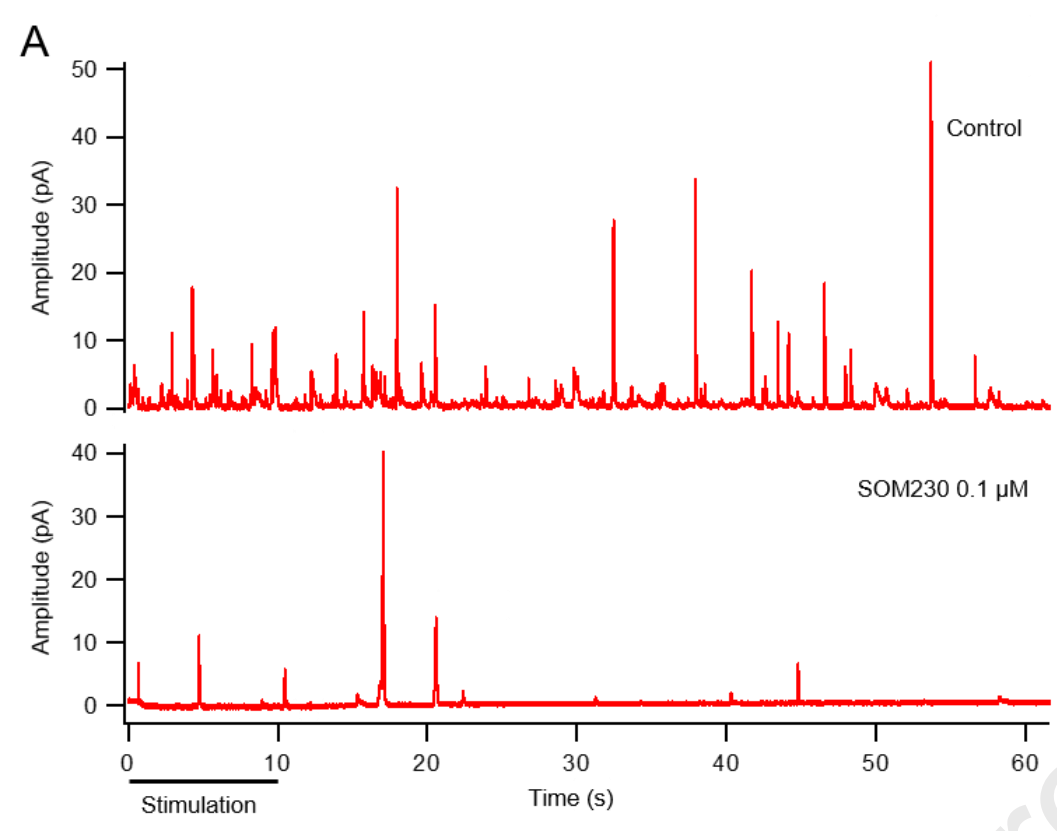

B

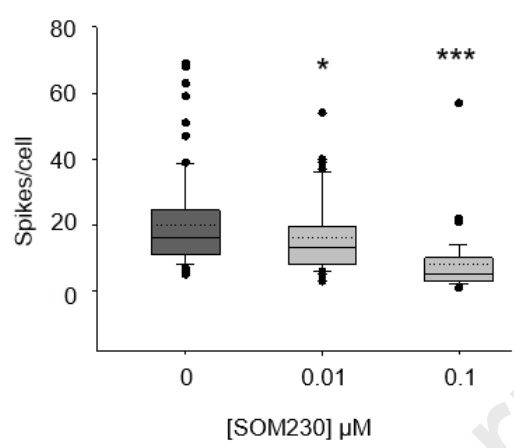

C

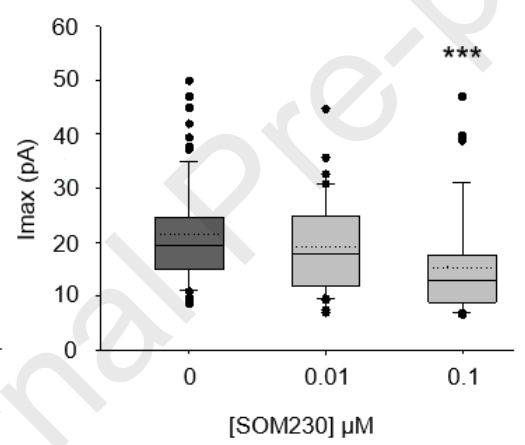

$\mathrm{D}$

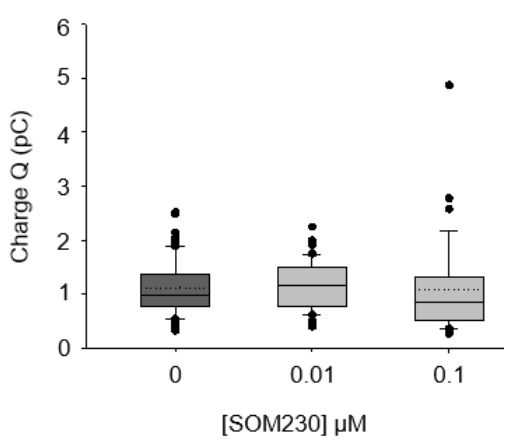

$\mathrm{E}$

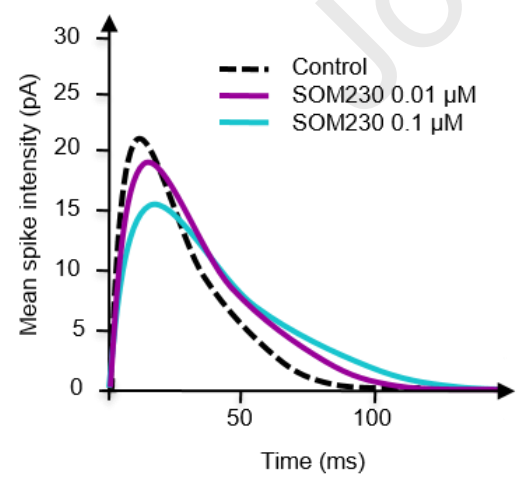

$\mathrm{F}$

\begin{tabular}{|c|c|c|c|}
\hline [SOM230] $\mu \mathrm{M}$ & 0 & 0.01 & 0.1 \\
\hline Number of cells & 93 & 40 & 39 \\
\hline Total num ber of spikes & 1865 & 645 & 312 \\
\hline Number of spikes/cell & $20.05 \pm 1.38$ & $16.13 \pm 1.72 *$ & $8.00 \pm 1.53 * * *$ \\
\hline Number of analyzed spikes & 1315 & 462 & 229 \\
\hline $\operatorname{lm} \operatorname{ax}(p A)$ & $21.33 \pm 0.96$ & $19.02 \pm 1.36$ & $15.34 \pm 1.54$ *** \\
\hline Charge $Q(p C)$ & $1.12 \pm 0.05$ & $1.16 \pm 0.07$ & $1.09 \pm 0.14$ \\
\hline $\mathrm{T}_{1 / 2}(\mathrm{~ms})$ & $51.33 \pm 1.77$ & $61.79 \pm 3.24$ ** & $64.24 \pm 3.90$ ** \\
\hline $\mathrm{T}_{\text {peak }}(\mathrm{ms})$ & $27.02 \pm 1.07$ & $33.86 \pm 2.03^{* *}$ & $35.40 \pm 2.53$ ** \\
\hline
\end{tabular}

Supplementary Figure 2. SOM230 in the culture medium affects different parameters of individual exocytotic events in single adrenal bovine chromaffin cells.

Bovine chromaffin cells were stimulated with a local application of $100 \mu \mathrm{M}$ nicotine for $10 \mathrm{~s}$ and catecholamine secretion was monitored using carbon fiber amperometry. (a) Example of a typical amperometric recording obtained from an untreated cell (control) or a cell treated with $0.1 \mu \mathrm{M}$ SOM230 in bath solution. (b) Box-and-whisker diagram illustrating the number of amperometric spikes per cell. Each plot represents the 1st quartile (bottom line), the median (line in the box), the mean (dotted line in the box) and the third quartile (upper line). Whiskers correspond to the 5th (bottom) and the 95th (top) 
percentile and black dots represent outlier observations; $* \mathrm{p}<0.05, * * * \mathrm{p}<0.001$ compared to control; Mann Whitney Rank Sum test. (c, d) Increasing concentration of SOM230 significantly affects the spike amplitude (Imax; (c)) but not the quantal size (Charge Q; (d)); ***p< 0.001 compared to control; Mann Whitney Rank Sum test. (e) The effect of SOM230 on spike shape is illustrated by superimposing average spikes according to cell treatment. (F) Table with all the average amperometric data; ${ }^{*} \mathrm{p}<0.05$, $* * p<0.01, * * * p<0.001$ compared to control; Mann Whitney Rank Sum test. 


\section{Supplementary Table. S1}

Elution gradient.

\begin{tabular}{|c|c|c|c|c|c|c|c|}
\hline Time (min) & 0 & 2.5 & 9 & 11 & 12 & 12.5 & 18 \\
\hline \% B mobile phase & 0 & 0 & 20 & 98 & 98 & 0 & 0 \\
\hline
\end{tabular}

Detail of MS analysis conditions.

\begin{tabular}{|c|c|}
\hline Mode & positive \\
\hline Spray voltage & $3,500 \mathrm{~V}$ \\
\hline Nebulizer gas & Nitrogen \\
\hline Desolvation (nitrogen) sheath gas & $18 \mathrm{Arb}$ \\
\hline Aux gas & $7 \mathrm{Arb}$ \\
\hline Ion transfer tube temperature & $297^{\circ} \mathrm{C}$ \\
\hline Vaporizer temperature & $131^{\circ} \mathrm{C}$ \\
\hline Q1 and Q2 resolutions & $0.7 \mathrm{FWHM}$, \\
\hline Collision gas (CID, argon) pressure & $2 \mathrm{mTorr}$ \\
\hline
\end{tabular}


Supplementary Table S2. Mass spectrometer ionization, selection, fragmentation, and identification parameters.

\begin{tabular}{|c|c|c|c|c|c|}
\hline Compound & Polarity & $\begin{array}{l}\text { Precursor } \\
(\mathrm{m} / \mathrm{z})\end{array}$ & $\begin{array}{l}\text { Product } \\
(\mathrm{m} / \mathbf{z})\end{array}$ & $\begin{array}{c}\text { Collision } \\
\text { Energy (V) }\end{array}$ & RF Lens (V) \\
\hline \multirow{3}{*}{ Dopamine } & \multirow{3}{*}{ positive } & \multirow{3}{*}{324.14} & 116.11 & 54.24 & \multirow{3}{*}{206} \\
\hline & & & 145.11 & 33.36 & \\
\hline & & & 171.05 & 23.90 & \\
\hline \multirow{3}{*}{ D4-Dopamine } & \multirow{3}{*}{ positive } & \multirow{3}{*}{328.14} & 116.11 & 55.00 & \multirow{3}{*}{206} \\
\hline & & & 128.05 & 48.67 & \\
\hline & & & 171 & 20.76 & \\
\hline \multirow{3}{*}{ Adrenaline } & \multirow{3}{*}{ positive } & \multirow{3}{*}{354.11} & 166.04 & 18.09 & \multirow{3}{*}{179} \\
\hline & & & 171.06 & 27.69 & \\
\hline & & & 184.04 & 14.60 & \\
\hline \multirow{3}{*}{ D6-Adrenaline } & \multirow{3}{*}{ positive } & \multirow{3}{*}{360.17} & 171.06 & 27.19 & \multirow{3}{*}{184} \\
\hline & & & 172.04 & 18.65 & \\
\hline & & & 190.04 & 14.35 & \\
\hline \multirow{3}{*}{ Noradrenaline } & \multirow{3}{*}{ positive } & \multirow{3}{*}{340.15} & 116.11 & 55.00 & \multirow{3}{*}{215} \\
\hline & & & 145.11 & 36.19 & \\
\hline & & & 171.06 & 24.61 & \\
\hline \multirow{3}{*}{$\begin{array}{c}\text { C6- } \\
\text { Noradrenaline }\end{array}$} & \multirow{3}{*}{ positive } & \multirow{3}{*}{346.15} & 145.11 & 36.04 & \multirow{3}{*}{226} \\
\hline & & & 158.11 & 18.34 & \\
\hline & & & 171.06 & 25.62 & \\
\hline
\end{tabular}



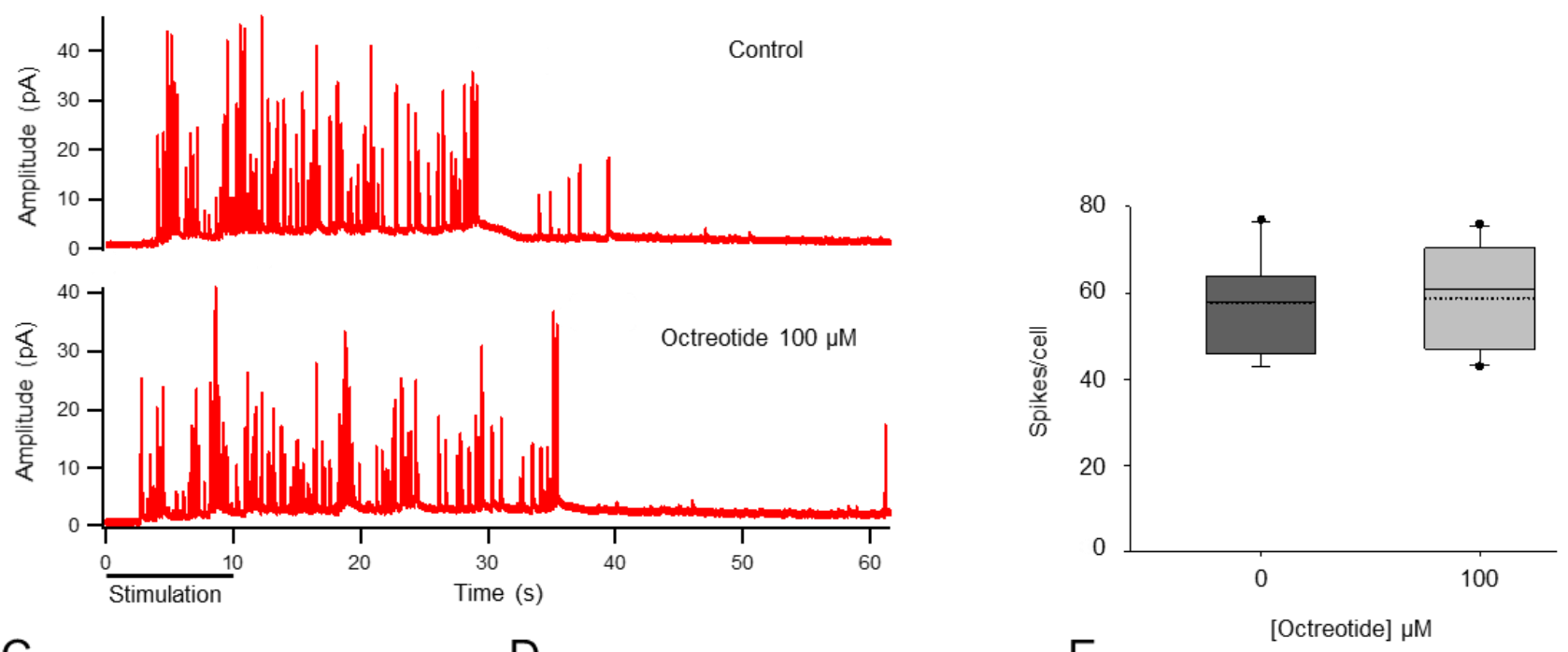

C

$\mathrm{D}$

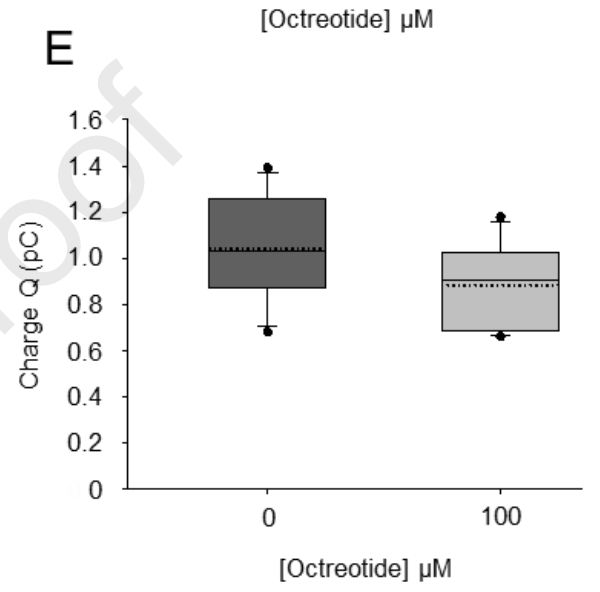

$\mathrm{F}$
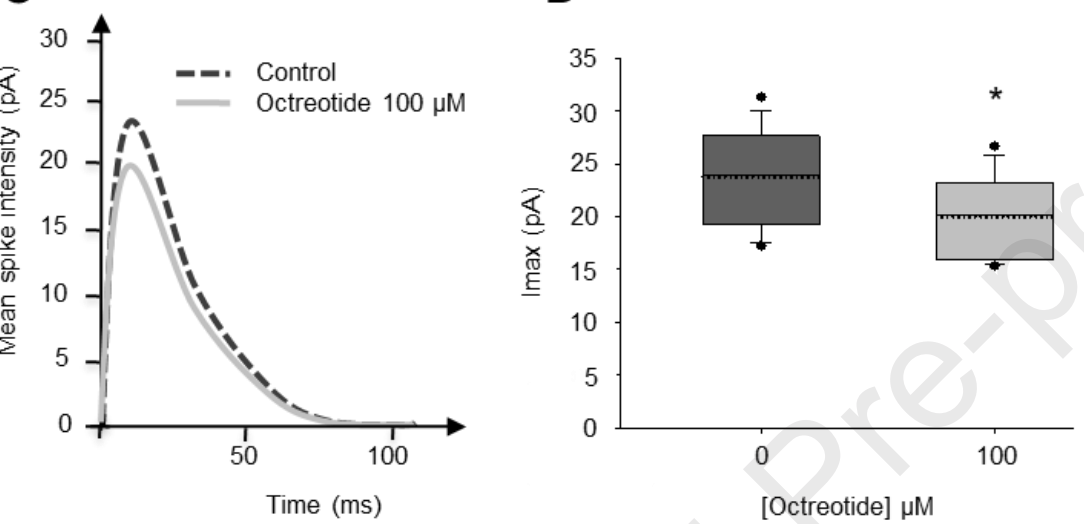

\begin{tabular}{lcc}
\hline [Octreotide] $\boldsymbol{\mu M}$ & $\mathbf{0}$ & $\mathbf{1 0 0}$ \\
\hline Number of cells & 15 & 13 \\
Total num ber of spikes & 866 & 764 \\
Number of spikes/cell & $57.73 \pm 2.76$ & $58.77 \pm 3.35$ \\
Number of analyzed spikes & 400 & 396 \\
Imax $(\mathrm{pA})$ & $23.72 \pm 1.15$ & $\mathbf{1 9 . 9 7 \pm 1 . 0 6}$ \\
Charge $\mathrm{Q}(\mathrm{pC})$ & $1.04 \pm 0.06$ & $0.88 \pm 0.05$ \\
$\mathrm{~T}_{1 / 2}(\mathrm{~ms})$ & $39.65 \pm 0.89$ & $39.04 \pm 1.01$ \\
$\mathrm{~T}_{\text {peak }}(\mathrm{ms})$ & $30.66 \pm 0.84$ & $30.38 \pm 0.91$ \\
\hline
\end{tabular}

\section{Supplementary Figure 3. Octreotide does not affect catecholamine secretion of human pheochromocytoma cells.}

Pheochromocytoma cells were stimulated with a local application of nicotine $100 \mu \mathrm{M}$ for $10 \mathrm{~s}$ and catecholamine secretion was monitored using carbon fiber amperometry. (a) Example of a typical amperometric recording obtained from an untreated cell (control) or a cell treated with $100 \mu \mathrm{M}$ octreotide in pipette (patient 2). (b) Box-and-whisker diagrams illustrate the number of amperometric spikes per cell. Each plot represents the 1st quartile (bottom line), the median (line in the box), the mean (dotted line in the box) and the third quartile (upper line). Whiskers correspond to the 5th (bottom) and the 95th (top) percentile and black dots represent outlier observations. (c) The effect of octreotide on spike shape is illustrated by superimposing average spikes according to cell treatment. (d, e) Octreotide significantly affects the spike amplitude (Imax; (d)) but not the quantal size (Charge Q; (e)); *p 0.05 compared to control; Mann Whitney Rank Sum test. (f) Table with all the average amperometric data; $* \mathrm{p}<0.05$ compared to control; Mann Whitney Rank Sum test. 


\begin{tabular}{|c|c|c|c|c|c|}
\hline [SOM230] $\mu \mathrm{M}$ & 0 & 0.1 & 1 & 10 & 100 \\
\hline Number of cells & 69 & 28 & 16 & 20 & 21 \\
\hline Total number of spikes & 2067 & 1043 & 125 & 110 & 155 \\
\hline Number of spikes/cell & $31.32 \pm 2.85$ & $37.25 \pm 4.24$ & $7.81 \pm 1.33^{\star \star \star}$ & $5.50 \pm 0.83^{\star \star \star}$ & $7.38 \pm 1.11^{\star \star \star}$ \\
\hline $\begin{array}{l}\text { Number of analyzed } \\
\text { spikes }\end{array}$ & 1463 & 735 & 57 & 53 & 72 \\
\hline $\operatorname{Imax}(p A)$ & $27.88 \pm 1.39$ & $23.84 \pm 1.76$ & $14.70 \pm 1.31$ *** & $18.87 \pm 1.41$ ** & $16.70 \pm 1.69 * * *$ \\
\hline Charge $Q(p C)$ & $1.42 \pm 0.09$ & $1.11 \pm 0.12$ * & $1.10 \pm 0.16$ & $1.30 \pm 0.14$ & $0.84 \pm 0.11^{* * *}$ \\
\hline $\mathrm{T}_{1 / 2}(\mathrm{~ms})$ & $46.10 \pm 1.86$ & $41.94 \pm 3.10$ & $65.49 \pm 6.62$ ** & $60.82 \pm 4.12$ ** & $43.62 \pm 2.17$ \\
\hline $\mathrm{T}_{\text {peak }}(\mathrm{ms})$ & $22.76 \pm 0.92$ & $21.95 \pm 2.06$ & $31.14 \pm 3.13^{\text {** }}$ & $29.75 \pm 2.40$ ** & $22.00 \pm 1.29$ \\
\hline
\end{tabular}

Table 1: Characteristics of amperometric spikes from bovine chromaffin cells treated with puff application of SOM230 in pipette. Amperometric recordings were performed on cultured bovine chromaffin cells. Cells were stimulated with $100 \mu \mathrm{M}$ of nicotine and the indicated SOM230 concentration for $10 \mathrm{~s}$. The number of cells, amperometric spikes per cell, amperometric spikes, and single-event kinetic parameters are indicated. Results represent the mean \pm SEM. Bold values are considered significantly different from the control condition; $* p<0.05, * * p<0.01, * * * p<0.001$ compared to control; Mann Whitney Rank Sum test. 


\begin{tabular}{|c|c|c|c|c|c|c|c|c|c|c|c|c|}
\hline$\#$ & Age & Gender & Symptoms & $\begin{array}{l}\text { Urinary } \\
\text { MN (ULN } \\
\text { ratio) }\end{array}$ & $\begin{array}{l}\text { Urinary } \\
\text { NMN } \\
\text { (ULN } \\
\text { ratio) }\end{array}$ & $\begin{array}{c}\text { Plasma } \\
\text { free MN } \\
\text { (ULN } \\
\text { ratio) }\end{array}$ & $\begin{array}{l}\text { Plasma } \\
\text { free NMN } \\
\text { (ULN } \\
\text { ratio) }\end{array}$ & $\begin{array}{c}\text { Plasma } \\
\text { CGA } \\
\text { (ULN } \\
\text { ratio) }\end{array}$ & $\begin{array}{l}\text { Size } \\
\text { (cm) }\end{array}$ & $\begin{array}{c}\text { Ki-67 } \\
(\%)\end{array}$ & $\begin{array}{l}\text { PASS } \\
\text { score }\end{array}$ & Genetics \\
\hline 1 & 47 & $\mathrm{~F}$ & Yes & 4.7 & 23.4 & - & - & 1.2 & 7 & 1 & 0 & Spor \\
\hline 2 & 58 & $\mathrm{~F}$ & Yes & - & - & 1.9 & 2.5 & - & 2 & 1 & 1 & NF1 \\
\hline 3 & 58 & $\mathrm{~F}$ & Yes & 2.8 & 10.4 & 4.4 & 7.4 & - & 3.5 & 1 & 4 & - \\
\hline 4 & 56 & $\mathrm{~F}$ & No & - & - & 4.9 & 8 & 4.9 & 4.9 & 1 & 1 & - \\
\hline 5 & 72 & $M$ & Yes & 10.3 & 9.6 & - & - & - & 6.5 & 1 & 2 & - \\
\hline 6 & 70 & $\mathrm{~F}$ & Yes & 1.4 & 5.6 & - & - & - & 3.5 & 2 & 2 & NF1 \\
\hline 7 & 52 & $\mathrm{~F}$ & No & 13.3 & 0.8 & 21.9 & 2.0 & - & 5 & 1 & 2 & - \\
\hline 8 & 61 & $M$ & No & 1.2 & 1.3 & 0.9 & 2.3 & 0.8 & 1.8 & 4.8 & 1 & - \\
\hline 9 & 77 & $M$ & Yes & 10.6 & 4.6 & - & - & - & 4 & 5 & 2 & - \\
\hline 10 & 72 & $M$ & Yes & 3.8 & 2.1 & 3.4 & 1.45 & 2.2 & 2.8 & 1.5 & 1 & - \\
\hline
\end{tabular}

Table 2: Clinical, biochemical, and functional characteristics of the 10 patients with pheochromocytoma evaluated in this study. Age at diagnosis, gender (F: female, M: male), the presence (Yes) or absence (No) of hormonal hypersecretion symptoms, biochemical and functional values are represented for each patient number (\#).MN: metanephrine, NMN: normetanephrine, ULN: upper limit normal, CGA: chromogranin A, PASS: Pheochromocytoma of the Adrenal Gland Scaled Score, Spor: sporadic, NF1: neurofibromatosis type 1, - : not available. 


\begin{tabular}{|c|c|c|c|c|c|c|c|c|c|c|}
\hline Identification & \multicolumn{2}{|c|}{ Treatment } & $\begin{array}{l}\text { Number of } \\
\text { cells }\end{array}$ & $\begin{array}{c}\text { Total number } \\
\text { of spikes }\end{array}$ & $\begin{array}{l}\text { Number of } \\
\text { spikes/cell }\end{array}$ & $\begin{array}{l}\text { Number of } \\
\text { analyzed }\end{array}$ & $\operatorname{Imax}(p A)$ & $\begin{array}{c}\text { Charge Q } \\
\text { (pC) }\end{array}$ & $\mathrm{T}_{1 / 2}(\mathrm{~ms})$ & $\mathrm{T}_{\text {peak }}(\mathrm{ms})$ \\
\hline \multirow[t]{2}{*}{ Patient 1} & \multirow{11}{*}{ 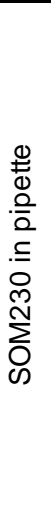 } & Control & 12 & 482 & $37.08 \pm 5.96$ & 334 & $21.58 \pm 2.30$ & $0.93 \pm 0.14$ & $37.39 \pm 2.83$ & $20.30 \pm 3.34$ \\
\hline & & $100 \mu \mathrm{M}$ & 13 & 61 & $4.69 \pm 1.87$ *** & 46 & $13.29 \pm 1.86$ * & $0.50 \pm 0.07$ * & $33.05 \pm 2.46$ & $13.84 \pm 1.40$ \\
\hline \multirow[t]{2}{*}{ Patient 2} & & Control & 15 & 866 & $57.73 \pm 2.76$ & 400 & $23.72 \pm 1.15$ & $1.04 \pm 0.06$ & $39.65 \pm 0.89$ & $30.66 \pm 0.84$ \\
\hline & & $100 \mu \mathrm{M}$ & 22 & 191 & $8.68 \pm 0.77^{* * *}$ & 70 & $19.75 \pm 1.58$ * & $0.98 \pm 0.11$ & $46.65 \pm 2.81$ * & $35.79 \pm 1.88$ * \\
\hline \multirow[t]{4}{*}{ Patient 3} & & Control & 9 & 379 & $42.11 \pm 5.25$ & 276 & $15.84 \pm 2.19$ & $0.60 \pm 0.10$ & $33.53 \pm 2.29$ & $16.95 \pm 1.58$ \\
\hline & & $0.1 \mu \mathrm{M}$ & 4 & 156 & $39.00 \pm 10.70$ & 110 & $16.28 \pm 3.38$ & $0.72 \pm 0.19$ & $39.57 \pm 2.33$ & $20.41 \pm 1.61$ \\
\hline & & $1 \mu \mathrm{M}$ & 12 & 287 & $23.92 \pm 2.05$ * & 170 & $14.99 \pm 0.91$ & $0.54 \pm 0.04$ & $33.06 \pm 1.86$ & $16.90 \pm 1.23$ \\
\hline & & $10 \mu \mathrm{M}$ & 7 & 132 & $18.86 \pm 4.58$ * & 107 & $19.16 \pm 4.80$ & $0.56 \pm 0.13$ & $28.50 \pm 1.42$ & $13.30 \pm 1.07$ \\
\hline \multirow[t]{3}{*}{ Patient 4} & & Control & 12 & 187 & $11.69 \pm 1.69$ & 118 & $13.28 \pm 1.23$ & $1.33 \pm 0.18$ & $91.26 \pm 6.40$ & $47.43 \pm 3.60$ \\
\hline & & $0.1 \mu \mathrm{M}$ & 11 & 112 & $10.18 \pm 3.83$ * & 76 & $7.96 \pm 0.73$ ** & $0.92 \pm 0.08$ & $105.13 \pm 4.56$ & $57.91 \pm 3.91$ \\
\hline & & $1 \mu \mathrm{M}$ & 14 & 63 & $4.50 \pm 1.39^{\star \star \star *}$ & 44 & $9.89 \pm 1.10$ & $1.12 \pm 0.18$ & $101.16 \pm 5.65$ & $54.60 \pm 3.49$ \\
\hline \multirow[t]{2}{*}{ Patient 5} & \multirow{11}{*}{ 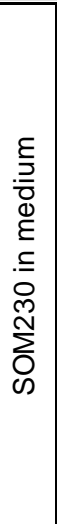 } & Control & 33 & 516 & $15.64 \pm 1.85$ & 4336 & $15.21 \pm 0.94$ & $1.11 \pm 0.06$ & $71.74 \pm 2.61$ & $35.78 \pm 1.40$ \\
\hline & & $0.1 \mu \mathrm{M}$ & 24 & 46 & $1.92 \pm 0.48^{\text {***}}$ & 40 & $10.73 \pm 2.86^{* \star *}$ & $0.90 \pm 0.15$ * & $80.76 \pm 5.36$ & $40.89 \pm 2.95$ \\
\hline \multirow[t]{4}{*}{ Patient 6} & & Control & 33 & 662 & $20.06 \pm 2.13$ & 556 & $19.44 \pm 2.15$ & $0.72 \pm 0.10$ & $34.32 \pm 2.07$ & $16.46 \pm 1.18$ \\
\hline & & $0.1 \mu \mathrm{M}$ & 23 & 201 & $8.74 \pm 1.74$ *** & 185 & $16.07 \pm 2.79$ & $0.66 \pm 0.12$ & $38.33 \pm 1.87$ & $19.55 \pm 1.37$ \\
\hline & & $1 \mu \mathrm{M}$ & 25 & 156 & $6.24 \pm 1.16^{* * *}$ & 138 & $13.09 \pm 1.50$ * & $0.49 \pm 0.06$ & $35.98 \pm 1.87$ & $17.82 \pm 1.07$ \\
\hline & & $10 \mu \mathrm{M}$ & 19 & 10 & $0.53 \pm 0.42^{\star * *}$ & 7 & - & - & - & - \\
\hline \multirow[t]{2}{*}{ Patient 7} & & Control & 22 & 627 & $28.50 \pm 4.86$ & 555 & $12.79 \pm 0.83$ & $0.68 \pm 0.04$ & $52.05 \pm 2.27$ & $25.85 \pm 1.40$ \\
\hline & & $0.1 \mu \mathrm{M}$ & 19 & 200 & $10.53 \pm 3.28^{* \star *}$ & 169 & $10.28 \pm 0.66$ * & $0.64 \pm 0.04$ & $59.30 \pm 2.55$ * & $31.72 \pm 1.69$ * \\
\hline \multirow[t]{3}{*}{ Patient 8} & & Control & 29 & 547 & $18.23 \pm 2.06$ & 449 & $12.91 \pm 0.88$ & $0.82 \pm 0.07$ & $61.66 \pm 3.54$ & $34.18 \pm 2.23$ \\
\hline & & $0.01 \mu \mathrm{M}$ & 21 & 355 & $16.90 \pm 3.43$ & 314 & $10.78 \pm 0.74$ * & $0.76 \pm 0.05$ & $65.91 \pm 3.09$ & $36.68 \pm 2.15$ \\
\hline & & $0.1 \mu \mathrm{M}$ & 24 & 254 & $10.58 \pm 2.13^{* *}$ & 224 & $15.63 \pm 1.67$ & $1.00 \pm 0.12$ & $60.18 \pm 2.74$ & $32.39 \pm 1.47$ \\
\hline
\end{tabular}

Table 3: Characteristics of amperometric spikes from 8 pheochromocytomas treated with SOM230. Amperometric recordings were performed on primary culture of human pheochromocytoma cells. Cells were stimulated with $100 \mu \mathrm{M}$ of nicotine and the indicated SOM230 concentration for $10 \mathrm{~s}$. For patients 1 to 4, SOM230 is in pipette stimulation and for patients 5 to 8, SOM230 is incubated in the cell medium. The number of cells, amperometric spikes per cell, amperometric spikes, and single-event kinetic parameters are indicated. Results represent the mean \pm SEM. Bold values are considered significantly different from the control conditions; $*_{\mathrm{p}}<0.05,{ }^{*} \mathrm{p}<0.01 ; * * \mathrm{p}<0.001$ compared to control; Mann Whitney Rank Sum test. 


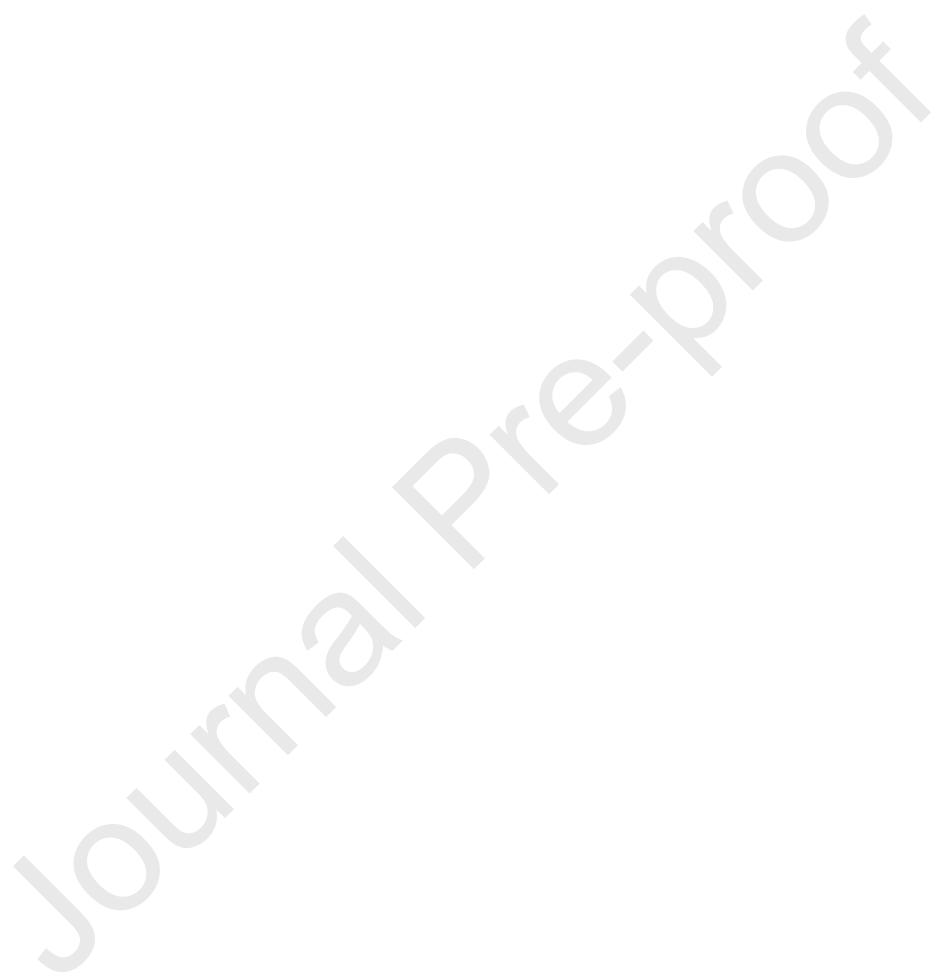




\section{Highlights}

- The somatostatin analogue Pasireotide (SOM230) inhibits catecholamine secretion in tumor cells cultured from freshly resected human pheochromocytoma.

- SOM230 inhibits catecholamine secretion by reducing the number of exocytic events per tumor cell.

- SOM230 inhibits nicotine-induced calcium influx and impact the function of the nicotinic receptor in pheochromocytoma cells.

- Treatment of pheochromocytoma cells with the somatostatin analogue octreotide has no effect on catecholamine secretion. 


\section{Declaration of interests}

$\bigotimes$ The authors declare that they have no known competing financial interests or personal relationships that could have appeared to influence the work reported in this paper.

$\square$ The authors declare the following financial interests/personal relationships which may be considered as potential competing interests:

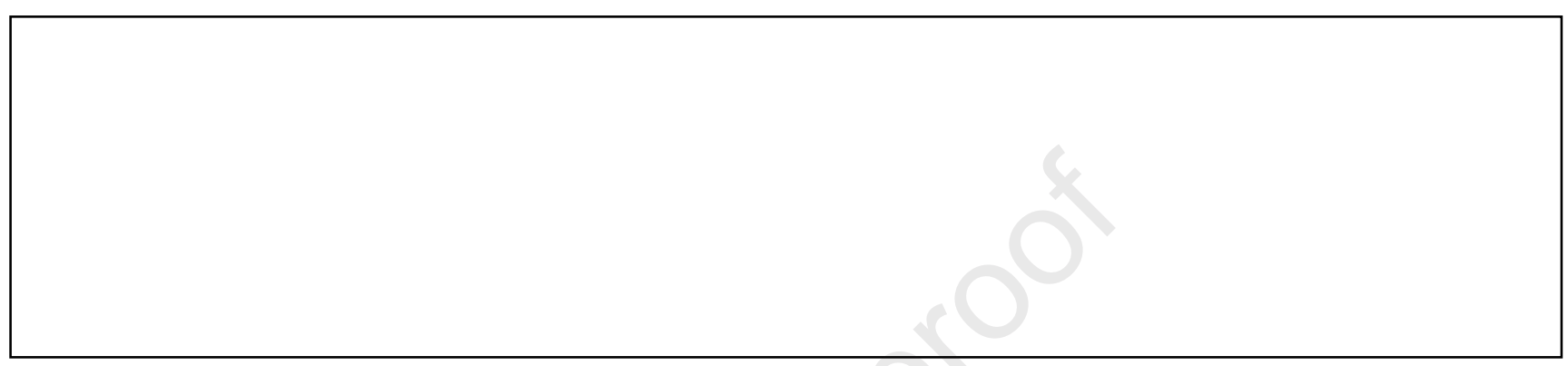

